\title{
Rare Metals (Ta-Nb-Sn) Mineralization Potential of Pegmatites of Igangan Area, Southwestern Nigeria
}

\author{
Olusegun G. Olisa ${ }^{1}$, Olugbenga A. Okunlola ${ }^{2}$, Ayotunde A. Omitogun ${ }^{2}$ \\ ${ }^{1}$ Department of Geology, Pan African University Life and Earth Science Institute, University of Ibadan, Ibadan, Nigeria \\ ${ }^{2}$ Department of Geology, University of Ibadan, Ibadan, Nigeria \\ Email: *segolisa@yahoo.com
}

How to cite this paper: Olisa, O.G., Okunlola, O.A. and Omitogun, A.A. (2018) Rare Metals (Ta-Nb-Sn) Mineralization Potential of Pegmatites of Igangan Area, Southwestern Nigeria. Journal of Geoscience and Environment Protection, 6, 67-88. https://doi.org/10.4236/gep.2018.64005

Received: December 6, 2017

Accepted: March 30, 2018

Published: April 2, 2018

Copyright $(9) 2018$ by authors and Scientific Research Publishing Inc. This work is licensed under the Creative Commons Attribution International License (CC BY 4.0).

http://creativecommons.org/licenses/by/4.0/

\begin{abstract}
The study was carried out to determine the rare metal mineralization potential of some pegmatites associated with metasediments in the Igangan $240 \mathrm{NW}$ sheet. Geological mapping on a scale of 1:50,000 revealed the pegmatites intrude metasediments and geochemical analysis for major, trace and rare earth elements were carried out using ICP MS/AES. Petrographic studies reveal a mineral assemblage of quartz, microcline and tourmaline; SEM studies revealed garnet and tourmaline to be close to the spessartine end-member and schorl respectively with albite occurring as the dominant plagioclase feldspar in the pegmatites. Result of geochemical analysis revealed $\mathrm{SiO}_{2}$ with an average of $73.91 \%$ in the whole rock pegmatite $\mathrm{Al}_{2} \mathrm{O}_{3}$ with an average of $13.93 \%$, and average concentration of $0.57 \%, 4.3 \%$ and $4.77 \%$ for $\mathrm{CaO}, \mathrm{Na}_{2} \mathrm{O}$ and $\mathrm{K}_{2} \mathrm{O}$ respectively. It also revealed average concentration of $29 \mathrm{ppm}, 153 \mathrm{ppm}, 30$ $\mathrm{ppm}, 118 \mathrm{ppm}$ and $129 \mathrm{ppm}$ for $\mathrm{W}, \mathrm{Li}, \mathrm{Ta}, \mathrm{Nb}$ and $\mathrm{Sn}$ in the mica respectively which is above the average values in the whole rock, felspars and tourmaline extracts. REE abundance in the whole rock pegmatites is low to moderate with LREE varying between $8-220 \mathrm{ppm}, 2-23 \mathrm{ppm}$ in feldspars and $3-32 \mathrm{ppm}$ in mica signifying no form of REE enrichment. Geochemical analysis results and trace elemental plots such as $\mathrm{K} / \mathrm{Rb}$ vs. $\mathrm{Rb}, \mathrm{Ta}$ vs. $\mathrm{Ga}$, Ta vs. Cs were used to assess rare metal mineralization and it revealed the pegmatites have low level of rare metal and rare earth element mineralization with average $\mathrm{k} / \mathrm{Rb}$ values of 177 indicative of low fractionation levels in the pegmatites.
\end{abstract}

\section{Keywords}

Rare Metals, Mineralization, Rare Earth Elements, Pegmatites 


\section{Introduction}

Pegmatites are economically important sources of ceramic materials and high technology metals such as $\mathrm{Rb}, \mathrm{Cs}, \mathrm{Be}$ and the high field strength elements [1]. Its genesis is a controversial topic based on the different ideas and schools of thought on its genesis. The entirety of pegmatite genesis is a continuum of increasing fractionation and increasing spatial order via segregation of internal mineral assemblages [2].

Granitic pegmatites are an important part of granitic intrusions in orogenic belts and are characterized by strong enrichment in incompatible elements such as $\mathrm{Rb}, \mathrm{Cs}, \mathrm{Li}, \mathrm{Be}$ and $\mathrm{Sn}$. They are also associated with $\mathrm{Nb}-\mathrm{Ta}-\mathrm{Sn}-\mathrm{W}$ mineralisation and the petrogenesis of pegmatites can be studied from the feldspar, mica and tourmaline which are sensitive indicators of magmatic and post magmatic events responsible for pegmatite evolution [3].

Various studies have been carried out on pegmatites in Nigeria by [4] [5] [6]. In the southwestern part of Nigeria, pegmatites are hosted within varieties of rocks of metamorphic and igneous origin where they intrude the older lithologies discordantly [7] [8] [9] [10] but there is paucity of information on pegmatites in Igangan sheet $240 \mathrm{NW}$.

Recent studies in Nigeria by [11] and [12] revealed that Nigeria has a pegmatite belt which is beyond the confines of the $400 \mathrm{~km} \mathrm{NE-SW}$ trending belt from Abeokuta, southwestern Nigeria to North Central Nigeria which previous authors thought they extend [13] [14]. [15] delineated the occurrence of new rare element pegmatites in Nigeria thereby revealing the possibility of more pegmatite bodies than previously thought. Geochronological studies have been carried out on Nigerian pegmatites with recent studies by [16] suggesting an age of 709 $\mathrm{Ma}$ for emplacement of pegmatites in Ede, southwestern Nigeria based on U-Pb zircon geochronology.

\section{Regional Geological Setting}

The study area falls within the basement complex of southwestern Nigeria, it lies within the Pan-African belt which resulted from the collision of the passive continental margin of the West-African Craton and the active margin of the Tuareg shield during the Pan African tectonic event (Figure 1, [17] [18] [19] [20]).

The Nigerian Precambrian basement complex bears the imprint of the Liberian (ca $2500 \mathrm{Ma}$ ), Eburnean (ca $2000 \mathrm{Ma}$ ) and Pan-African (ca $600 \mathrm{Ma}$ ) tectonic events; it is polycyclic and can be broadly grouped into the migmatite gneiss complex, the schists belts and the older granite suite (Figure 2, [21] [22] [23] [24] [25]).

The migmatite gneiss complex consists mainly of migmatites and gneisses of different origin as well as meta-igneous rocks of basic to ultrabasic composition; the schist belts consists of fine grained clastics, pelitic schists, phyllites, banded iron formations, marble and amphibolites with imprints of the Kibaran (ca. 1200 Ma) and Pan African tectonic events [26], while the older granites consist of 


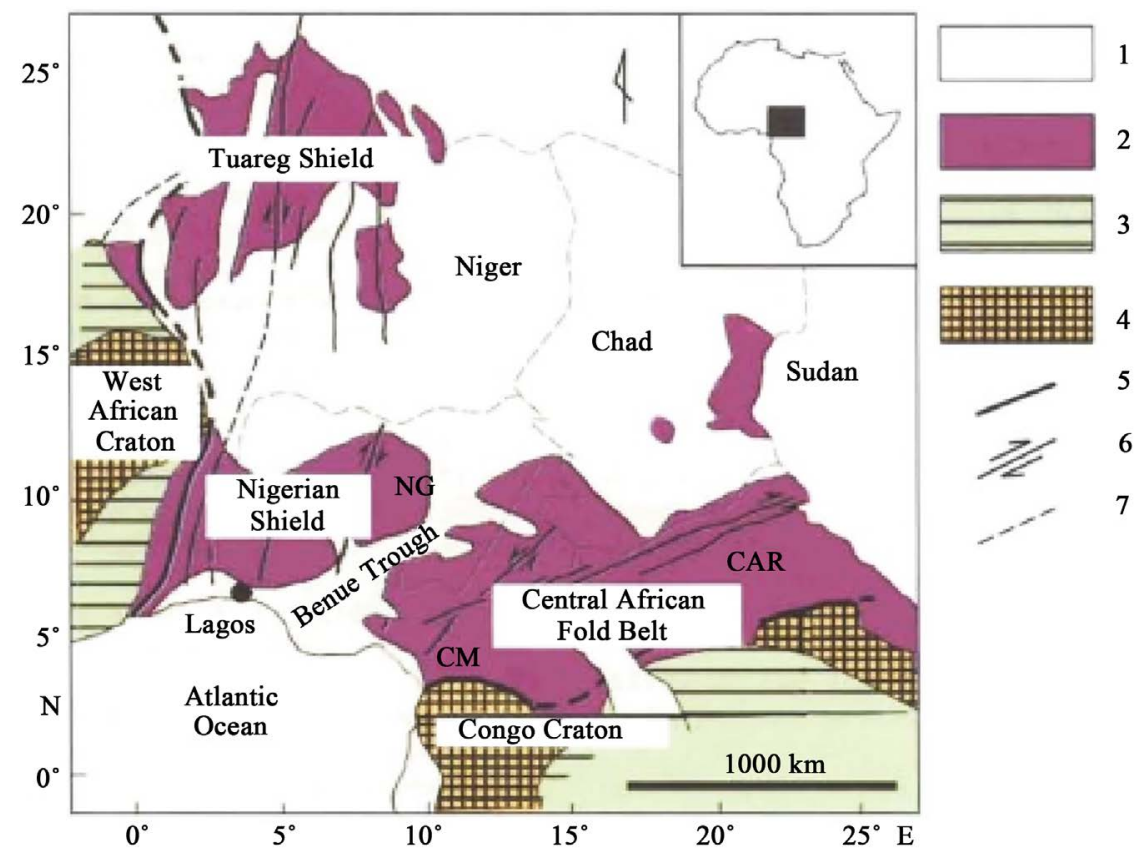

Figure 1. Sketch map showing Pan-African domains in West Central Africa. 1. Post-Pan African domains, 2. Pan African domains, 3. Pre-Mesozoic platform deposits, 4. Archean to Paleoproterozoic cratons, 5. Craton limits, 6. Major strike-slip faults, 7. State boundaries. CAR: Central African Republic, CM: Cameroun, NG: Nigeria (Modified after [27]).

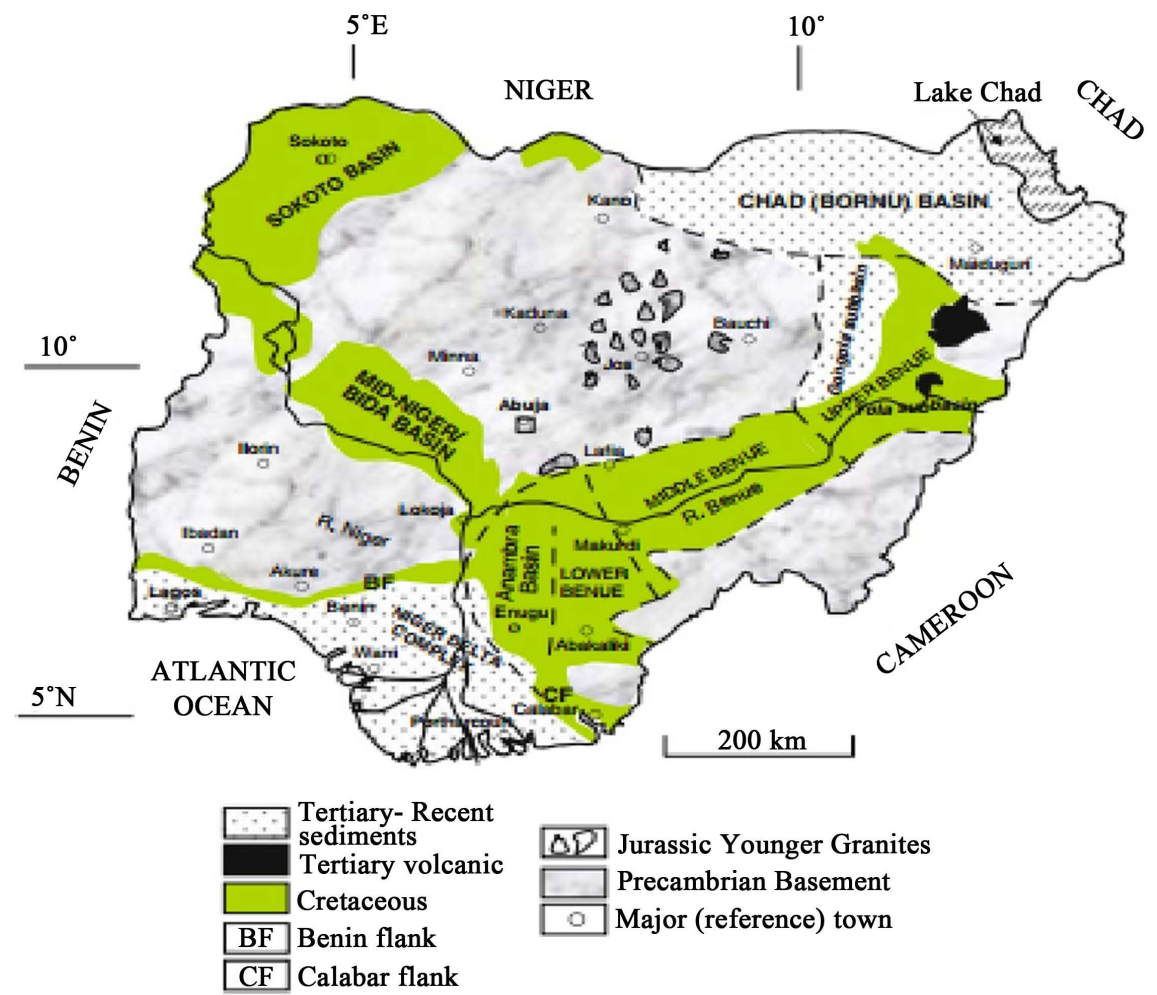

Figure 2. Geological sketch map of Nigeria showing the major geological components (Adapted from [28]). 
orogenic (Pan-African) igneous rocks emplaced in the migmatite gneiss complex and the schists belts with varied lithology of granites, granodiorites, diorites, tonalities, syenites and pegmatites.

\section{Local Geological Setting}

The lithologies in the study areas include porphyritic granites, schists, biotite granites, granite gneisses as well as charnockites and amphibolites. These rocks are intruded by dolerite, granitic dykes, pegmatites quartz veins and aplites of varying length and thickness.

In the study area, the northwestern and northeastern flank is predominantly granitic, the southeastern flank and south central flank is dominantly by granite gneisses and migmatites with the central flank of the study area being dominantly schistose in nature with intercalations of quartzite and dolerite dykes occurring in the northeastern flank of the study area as intrusions associated with quartzites while the charnokites and amphibolites occurs as pods mostly within the schists (Figure 3).

Pegmatites occur as intrusions of various dimensions, varying length and thicknesses some of which crosscut the host rocks, it has interlocking grains of quartz, feldspars and in some cases minor traces of biotite, muscovite, garnet, tourmaline and agate; it follows a NW/SE trend with massive deposits occurring in the central portion of the study area as intrusions within the mica schist (Figure 4).

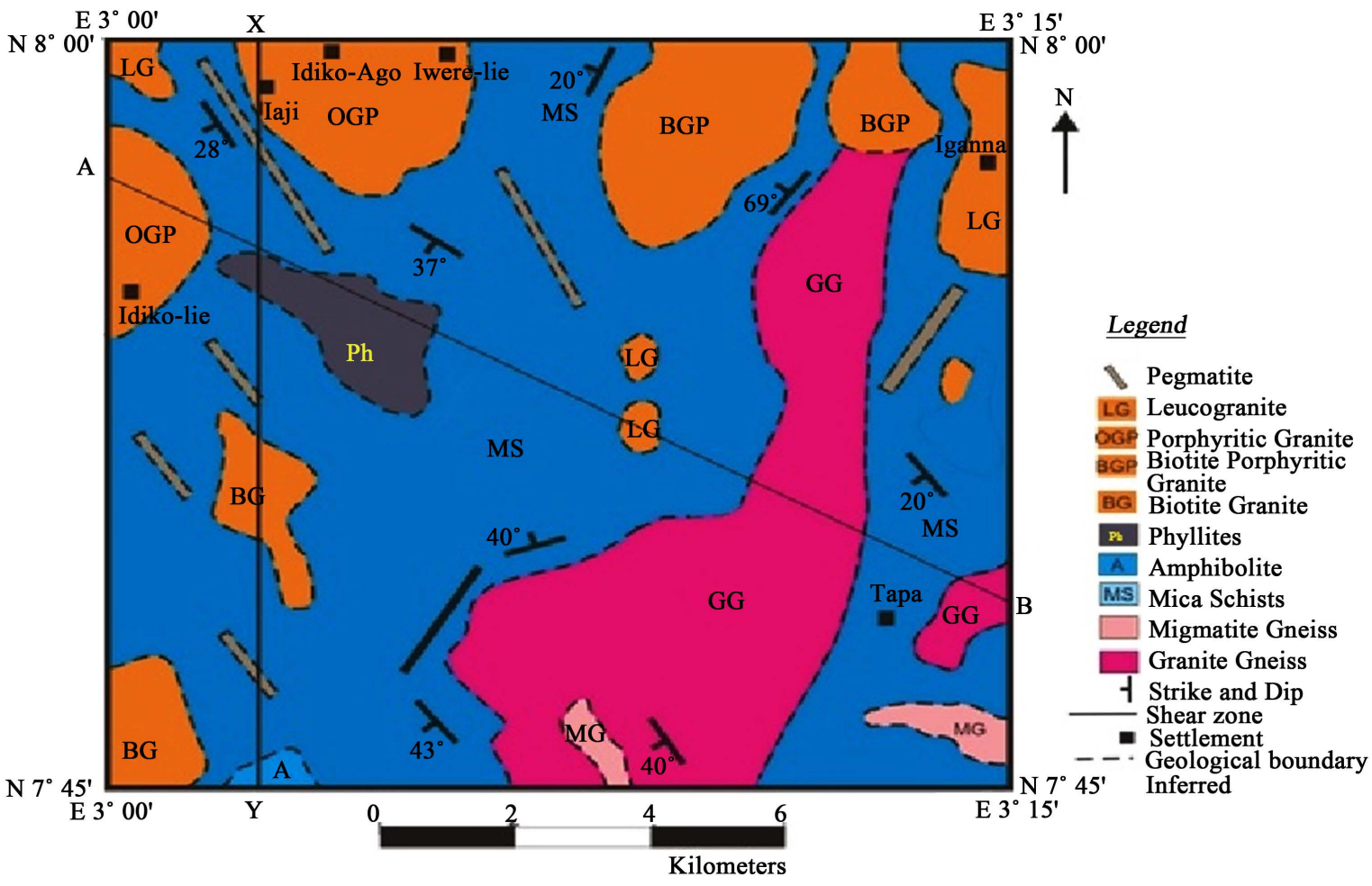

Figure 3. Geological map of the study area. 


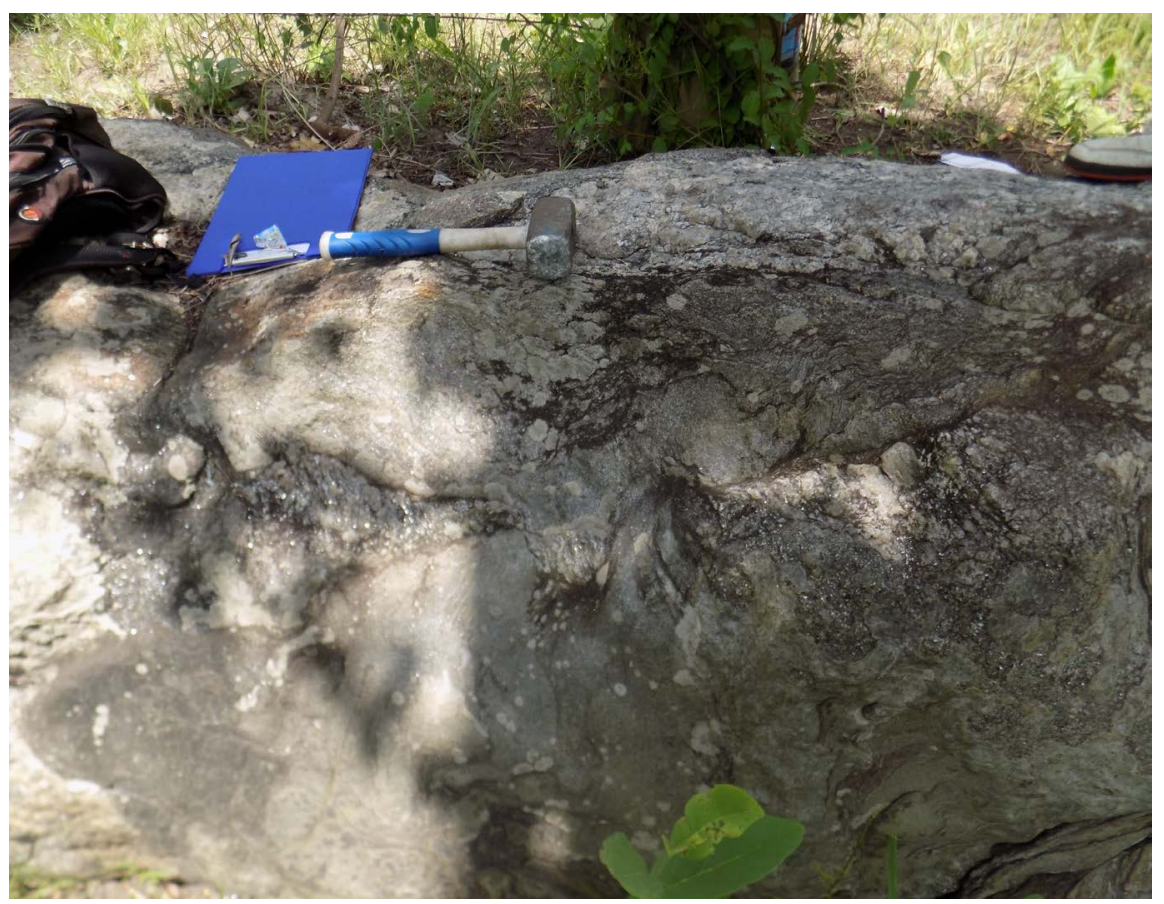

Figure 4. Schist pegmatite contact (hammer is about $30 \mathrm{~cm}$ in length).

Pegmatites are typically coarse grained but they show great variation in grain size, the contact between pegmatite and host rock are sharp in the granites, migmatites and granite gneisses while the contact in the schists was rarely observed due to the friable nature of the schists. Pegmatites associated with the porphyritic granites, migmatites and granite Gneisses are simple pegmatites dykes with central quartz bounded by feldspar, they are not extensive, they have similar mineralogy of quartz, microcline and occurrence of schorl in some areas while the pegmatites associated with the schist are mostly extensive and possess varying mineralogy with feldspars varying from orthoclase to albite, tourmaline, garnet, fluorite and tourmaline amongst others.

The polycyclic nature of the Nigerian basement complex is evident in the area with structural features such as faults and folds observed mainly in the migmatite gneiss and the NW/SE trend of the pegmatite as well as the NW/SE and $\mathrm{NE} / \mathrm{SW}$ orientation of the joints with the NW/SE direction the main orientation of joints in the area. Some of the pegmatite bodies predate some of the structural features, this evident by structural deformation which manifest by brittle/ductile fault offsets by the structural episode.

They lack any form of foliation and they show no form of regional zoning, this could be due to the lower volatile contents of parent melts and the emplacement of their parental granitic melts at relatively shallow depth. Although variations in mineraology and field features in the pegmatites are obvious, it was not possible to investigate the changes in the bulk chemistry of the host rocks related to pegmatite formation due to the lack of clear cut contact zones between the pegmatites and the schists in some areas and the level of weathering of the metasedi- 
ments. Presently, no geochronological data is available for rocks in the study area but studies are ongoing to acquire absolute age for the granites and pegmatites.

\section{Method of Study}

Field work involved systematic geological mapping on the scale of 1:50,000 to delineate the geological units in an area extending from $3^{\circ} 00^{\prime}-3^{\circ} 15^{\prime}$ and $7^{\circ} 45^{\prime}$ $8^{\circ} 00^{\prime}$ with an area extent of about $829 \mathrm{~km}^{2}$. It involved the direct observation of the rocks in the study area, their structures features as well as their basic mineralogy.

During the study, lithological relationship between the pegmatites and host rocks was established; pegmatites samples were collected, thin sections as well as polished sections of the pegmatites were carried out at the department of geology, Rhodes University, Republic of South Africa and geochemical analysis was carried at Bureau Veritas Mineral Commodities, Canada.

Samples for polished sections were cut into $\sim 2 \mathrm{~cm}$ diameter $\mathrm{x} \sim 1 \mathrm{~cm}$ rock fragments and mounted in epoxy. They were then polished with $3 \mu \mathrm{m}$ and then 1 $\mu \mathrm{m}$ diamond paste, carbon coated with a Q150T Turbo-Pumped Sputter Coater/ Carbon and analysed with a Jeol JSM6610 SEM equipped with a Thermo Fisher Ultradry EDS detector. Polished sections were examined using back-scattered electron imagery in an attempt to detect phases with high back-scattered electron intensity. These were subsequently analysed by means of energy dispersive $\mathrm{X}$-ray spectrometry in order to determine the chemical composition of the phases. Analysis was carried out at the University of Free State, South Africa.

\section{Results and Discussion}

\subsection{Mineralogy and Petrography}

Hand samples of pegmatites vary from samples with a graphic texture composed of orthoclase and quartz with low percentage of mica, to pegmatites with albite/othoclase bond to a central quartz and muscovite with rare biotite; the presence of muscovite over biotite in the pegmatites is an indication of the general peraluminous nature of the pegmatite.

Petrographic studies revealed a mineral assemblage of quartz, microcline and tourmaline with accessory minerals that are opaque. Quartz display a low positive relief under crossed nicols while microcline displayed cross hatched twinning; albite displayed a polysynthethic albite twinning with perthitic habit indicating the intergrowth of two feldspars.

Potassium feldspars consist mostly of orthoclase which shows varying degrees of perthitic intergrowth, sodium felspars which are mainly albite; feldspars probed by SEM are mainly albites with very few of the plagioclase probed having compositions tending towards oligoclase.

Quartz occurs in all the pegmatites as an intergrowth with feldspars in some 
outcrops and as well developed euhedral crystals in some locations; it is mainly colorless in the pegmatites and composed almost entirely of $\mathrm{SiO}_{2}$ based on SEM analysis. Micas occurs as muscovites and rarely as biotite with the presence of muscovite over biotite in the pegmatites an indication of the general peraluminous nature of the pegmatites.

The predominant minor minerals are garnet and tourmaline. Garnet is very rare in the pegmatites and was only observed at the only pegmatite/schist contact while tourmaline is also rare but more common than garnet, it is black in color and presumed to be schorl.

Garnet is euhedral with inclusions of apatite (Figure 5, Figure 6, Table 1) and composition close to the spessartine end-member with a formula; $\mathrm{Mn}_{3}^{2+} \mathrm{Al}_{2}\left(\mathrm{SiO}_{4}\right)_{3}$; garnet chemistry reveals the chemical evolution of the phase from which the garnets crystallized and the presence of a garnet end member

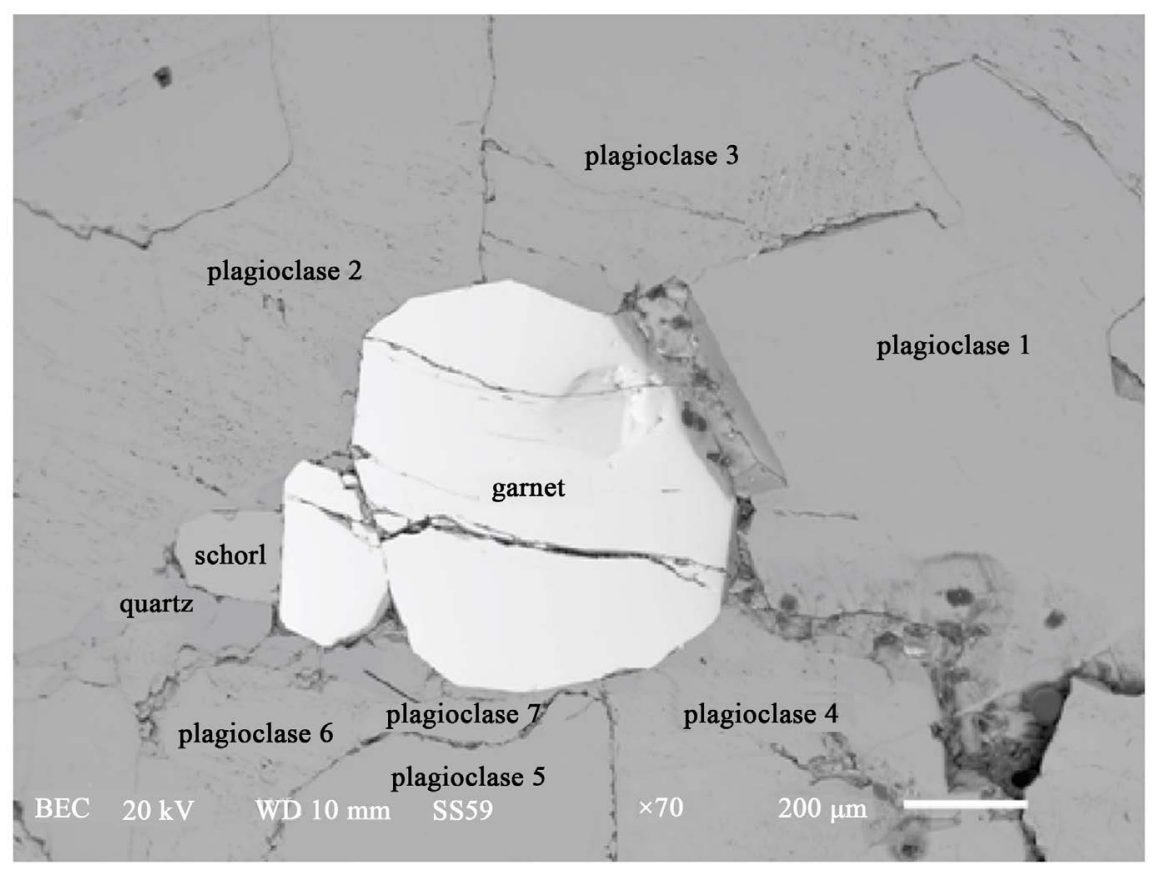

Figure 5. Backscatter electron image of quartz, schorl and plagioclase in pegmatite

Table 1. Composition of garnet probed by SEM.

\begin{tabular}{|c|c|c|c|c|c|c|c|c|c|c|c|}
\hline $\mathrm{F}$ & $\mathrm{Na}_{2} \mathrm{O}$ & $\mathrm{MgO}$ & $\mathrm{Al}_{2} \mathrm{O}_{3}$ & $\mathrm{SiO}_{2}$ & $\mathrm{P}_{2} \mathrm{O}_{5}$ & $\mathrm{~K}_{2} \mathrm{O}$ & $\mathrm{CaO}$ & $\mathrm{TiO}_{2}$ & $\mathrm{MnO}$ & $\mathrm{Fe}_{2} \mathrm{O}_{3}$ & $\mathrm{Ta}_{2} \mathrm{O}_{5}$ \\
\hline 1 & - & 1.34 & 17.16 & 32.40 & - & - & 0.53 & - & 29.95 & 18.63 & - \\
\hline 2 & - & 0.43 & 17.24 & 31.99 & - & - & 1.09 & - & 24.41 & 24.84 & - \\
\hline 3 & - & 0.54 & 17.28 & 32.23 & - & - & 1.08 & - & 24.10 & 24.77 & - \\
\hline 4 & - & 0.59 & 17.54 & 32.34 & - & - & 1.14 & - & 23.66 & 24.75 & - \\
\hline 5 & - & 0.61 & 17.36 & 32.41 & - & -- & 1.07 & - & 23.97 & 24.58 & - \\
\hline 6 & - & 0.66 & 17.31 & 32.39 & - & - & 1.15 & - & 23.32 & 25.16 & - \\
\hline 7 & - & 0.56 & 17.30 & 32.07 & - & - & 1.11 & - & 24.15 & 24.82 & - \\
\hline
\end{tabular}


can be used to draw inference on the possible petrogenesis of granitic magma and the approximate depth of formation and garnets from the study plots in the field of igneous (Figure 7).

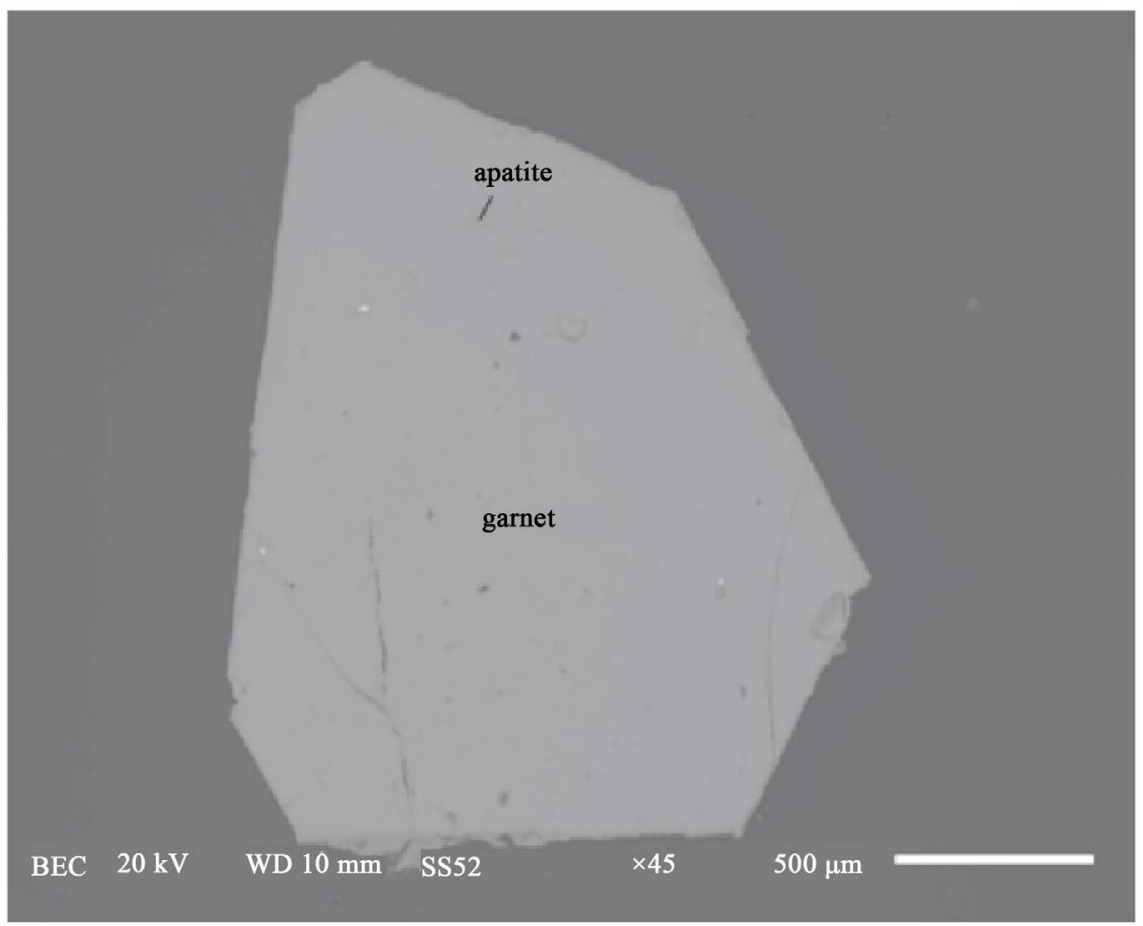

Figure 6. Garnet and plagioclase in pegmatite and backscatter electron image of garnet rain mount with inclusions of apatite.

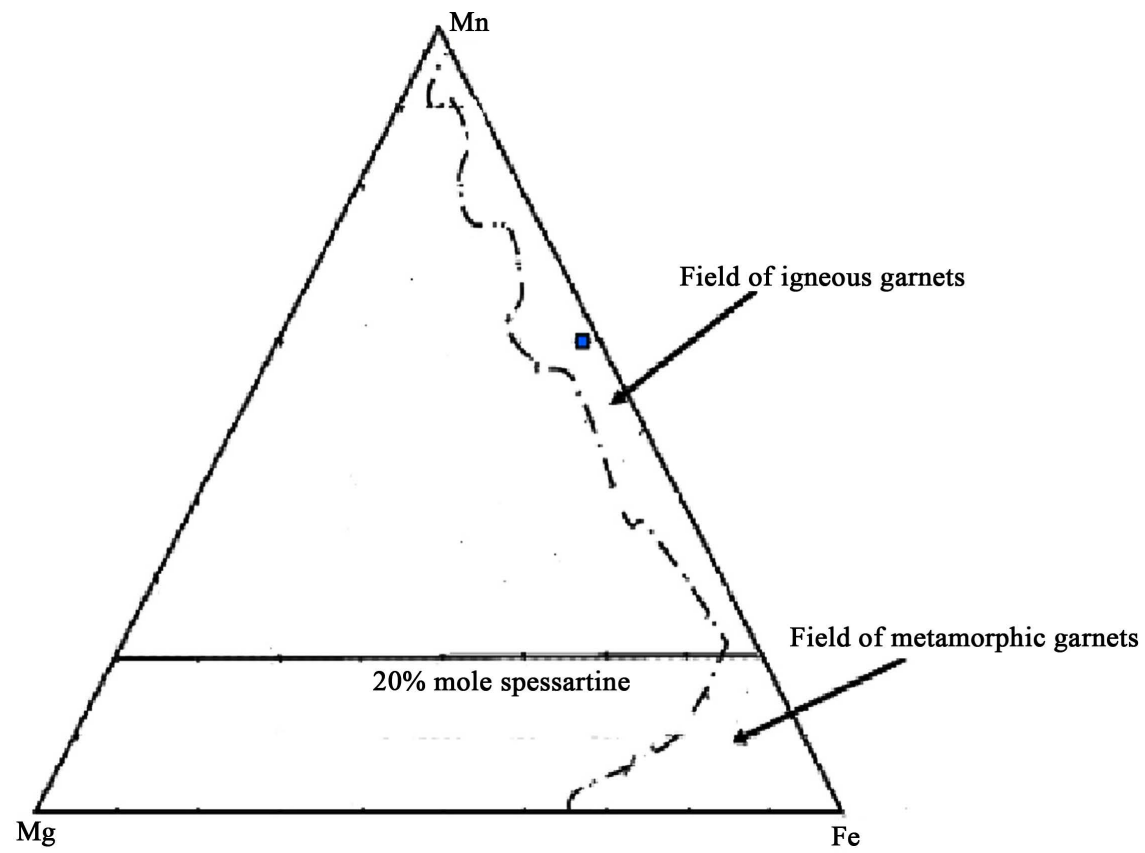

Figure 7. Composition of garnet. (a) Mn-Mg-Fe plot superimposed with the compositional field of igneous garnet [29]. 
SEM analysis revealed garnets have high concentration of $\mathrm{SiO}_{2}, \mathrm{MnO}, \mathrm{Fe}_{2} \mathrm{O}_{3}$ and $\mathrm{Al}_{2} \mathrm{O}_{3}$, and low concentration of $\mathrm{Na}_{2} \mathrm{O}$ and $\mathrm{CaO}$ while $\mathrm{P}_{2} \mathrm{O}_{5}, \mathrm{~K}_{2} \mathrm{O}, \mathrm{Ta}_{2} \mathrm{O}_{5}$, $\mathrm{TiO}_{2} \mathrm{CaO}$ concentrations were not obtained from the analysis (Table 1) while inclusions of apatite contains high concentration of $\mathrm{P}_{2} \mathrm{O}_{5}(39.9 \%), \mathrm{CaO}(50.8 \%)$, $\mathrm{MnO}$ (4.48\%) and $\mathrm{F}$ (3.45\%); a composition indicative of flouroapatite.

\subsection{Tourmaline}

Analysis of tourmaline did not reveal the crystal structures of the tourmaline grains (Figure 8); tourmalines have high concentration of $\mathrm{Al}_{2} \mathrm{O}_{3}, \mathrm{Fe}_{2} \mathrm{O}_{3}$ and $\mathrm{SiO}_{2}$ with average concentration of $36.2 \%, 14.9 \%$ and $40.6 \%$ respectively; low concentration of $\mathrm{Na}_{2} \mathrm{O}$ and $\mathrm{MgO}$ with average concentration of $2.7 \%$ and $4.5 \%$ respectively while concentration of $\mathrm{CaO}, \mathrm{TiO}_{2}, \mathrm{MnO}$ and $\mathrm{BaO}$ are below $0.6 \%$.

The tourmaline falls into the class of Fe rich quartz tourmaline rocks (hydrothermally altered granites), an indicating of boron metasomatism during the late stage crystallization of the pegmatites ([30], Table 2 and Figure 9).

SEM analysis of feldspars reveal average concentration of $9.99 \%, 20.50 \%$, $64.50 \%, 0.03 \%, 0.08 \%, 0.26 \%$ and $0.41 \%$ for $\mathrm{Na}_{2} \mathrm{O}, \mathrm{MgO}, \mathrm{Al}_{2} \mathrm{O}_{3}, \mathrm{SiO}_{2}, \mathrm{P}_{2} \mathrm{O}_{5}, \mathrm{~K}_{2} \mathrm{O}$, $\mathrm{CaO}, \mathrm{Fe}_{2} \mathrm{O}_{3}$ and $\mathrm{ZnO}$ respectively indicative of albite as the dominant plagioclase in the pegmatites (Table 3 ).

\subsection{Geochemistry of Pegmatites}

In terms of major elements the whole rock pegmatite samples have the highest concentration of silica and $\mathrm{CaO}$ with average of $73.91 \%$ and $0.57 \%$ respectively, the feldspar extracts have the highest concentration of $\mathrm{Na}_{2} \mathrm{O}$ and $\mathrm{P}_{2} \mathrm{O}_{5}$ with a

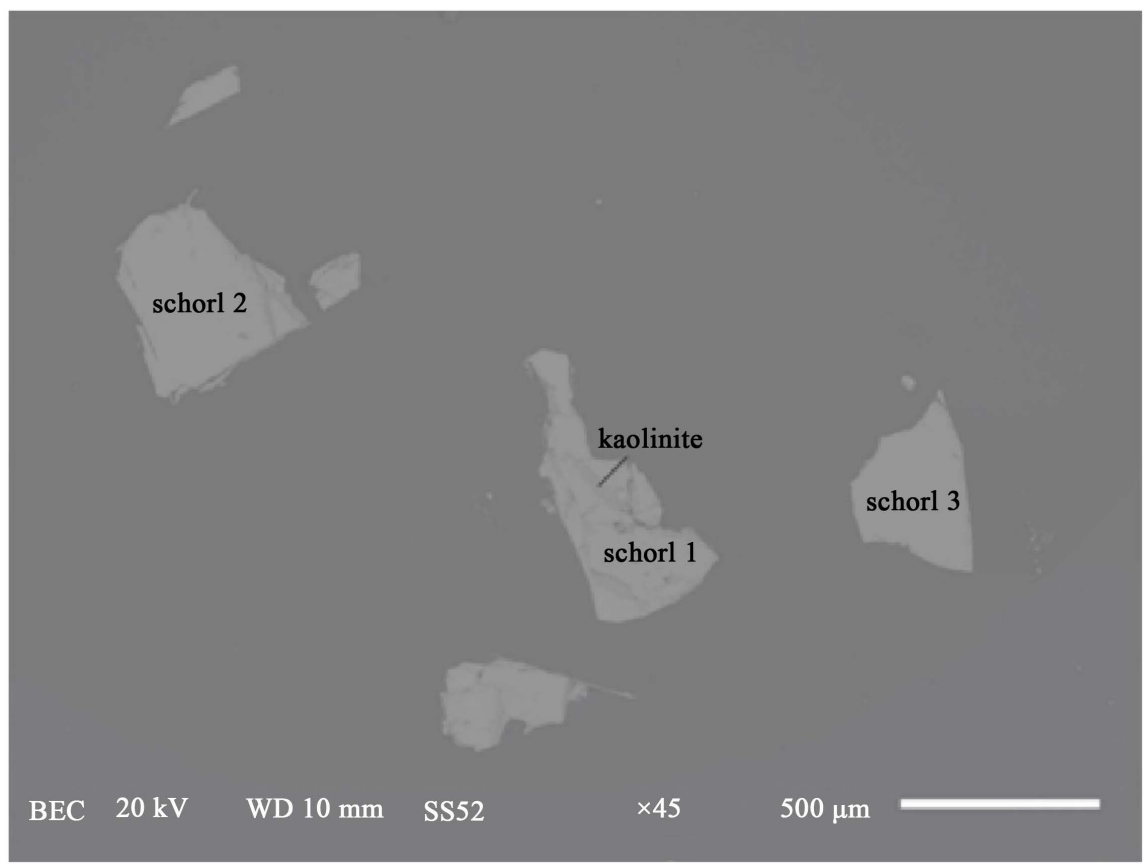

Figure 8. Backscatter electron image showing schorl associated with kaolinite. 


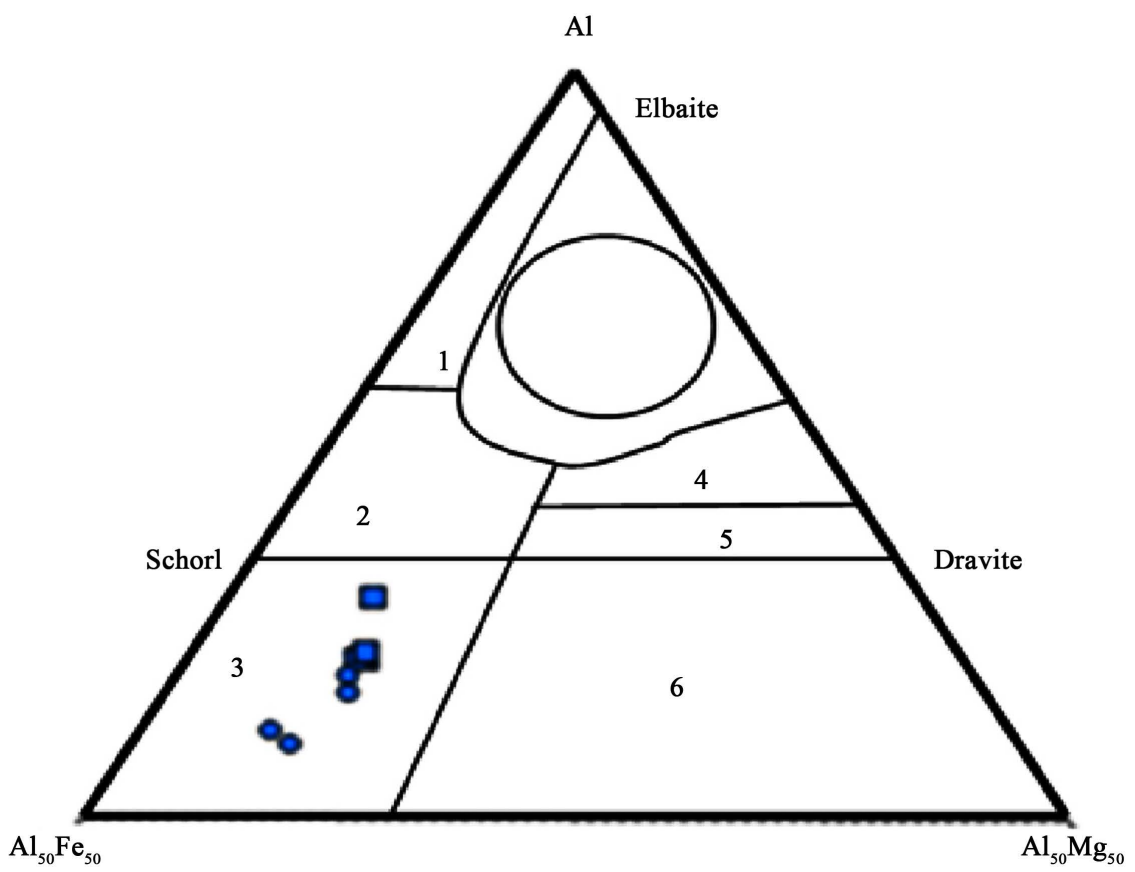

Figure 9. Composition of tourmaline from the study area. Al-Fe-Mg relations with fields of tourmaline (after [30]) from (1) Li-rich granitoid pegmatites and aplites, (2) Li-poor granitoids and their associated pegmatites and aplites, (3) Fe3+-rich quartztourmaline rocks (hydrothermally altered granites), (4) metapelites coexisting with Al-saturating phase, (5) metapelites not coexisting with Al-saturating phase, (6) Fe3+-rich quartztourmaline rocks, calc-silicate rocks, and metapelites.

Table 2. Composition of tourmaline from SEM.

\begin{tabular}{cccccccccccccc}
\hline & $\mathrm{F}$ & $\mathrm{Na}_{2} \mathrm{O}$ & $\mathrm{MgO}$ & $\mathrm{Al}_{2} \mathrm{O}_{3}$ & $\mathrm{SiO}_{2}$ & $\mathrm{P}_{2} \mathrm{O}_{5}$ & $\mathrm{~K}_{2} \mathrm{O}$ & $\mathrm{CaO}$ & $\mathrm{TiO}_{2}$ & $\mathrm{MnO}$ & $\mathrm{Fe}_{2} \mathrm{O}_{3}$ & $\mathrm{ZnO}$ & $\mathrm{BaO}$ \\
\hline 1 & - & 2.50 & 4.84 & $\mathbf{3 6 . 9 2}$ & $\mathbf{4 0 . 9 8}$ & - & - & 0.11 & 0.06 & 0.53 & $\mathbf{1 4 . 0 2}$ & 0.02 & 0.05 \\
2 & - & 2.44 & 4.65 & $\mathbf{3 6 . 7 9}$ & $\mathbf{4 1 . 1 5}$ & - & - & 0.16 & 0.21 & 0.49 & $\mathbf{1 4 . 1 3}$ & - & - \\
3 & - & 2.70 & 4.77 & $\mathbf{3 6 . 9 7}$ & $\mathbf{4 1 . 0 3}$ & - & - & 0.13 & - & 0.50 & $\mathbf{1 3 . 8 5}$ & - & 0.06 \\
4 & - & 2.38 & 3.79 & $\mathbf{3 8 . 1 4}$ & $\mathbf{4 1 . 4 8}$ & - & - & 0.56 & 0.20 & 0.96 & $\mathbf{1 2 . 5 1}$ & - & - \\
5 & - & 2.53 & 4.70 & $\mathbf{3 6 . 1 6}$ & $\mathbf{4 0 . 9 2}$ & - & - & 0.29 & 0.24 & 0.48 & $\mathbf{1 4 . 6 1}$ & - & 0.07 \\
6 & - & 2.73 & 4.99 & $\mathbf{3 5 . 3 5}$ & $\mathbf{4 0 . 7 9}$ & - & - & 0.30 & 0.43 & 0.50 & $\mathbf{1 4 . 9 0}$ & - & 0.15 \\
7 & - & 2.72 & 3.67 & $\mathbf{3 4 . 6 6}$ & $\mathbf{3 9 . 5 7}$ & - & - & 0.52 & 0.81 & 0.36 & $\mathbf{1 7 . 7 0}$ & - & - \\
8 & - & 3.26 & 4.52 & $\mathbf{3 4 . 2 5}$ & $\mathbf{3 9 . 1 8}$ & - & - & 0.68 & 0.60 & - & $\mathbf{1 7 . 5 1}$ & - & - \\
\hline
\end{tabular}

verage concentration of $5.77 \%$ and $0.14 \%$ while the mica extracts have the highest concentration of $\mathrm{Al}_{2} \mathrm{O}_{3}(16.42 \%), \mathrm{Fe}_{2} \mathrm{O}_{3}(2.11 \%), \mathrm{MnO}$ (0.08\%), $\mathrm{MgO}(0.42 \%)$ and $\mathrm{K}_{2} \mathrm{O}(5.66 \%)$.

In terms of trace elements, for $\mathrm{Nb}, \mathrm{Sn}$ and $\mathrm{W}$ average concentration in whole rocks exceeds that of the other extracts (whole rock $>$ mica $>$ feldspar $>$ tourmaline). For Ta, elemental abundance is highest in micas and least in tourmaline (mica $>$ feldspar $>$ whole rock $>$ tourmaline), Cs abundance is highest in the 
Table 3. Composition of plagioclase from SEM.

\begin{tabular}{|c|c|c|c|c|c|c|c|c|c|c|c|c|}
\hline & F & $\mathrm{Na}_{2} \mathrm{O}$ & $\mathrm{Al}_{2} \mathrm{O}_{3}$ & $\mathrm{SiO}_{2}$ & $\mathrm{~K}_{2} \mathrm{O}$ & $\mathrm{CaO}$ & $\mathrm{TiO}_{2}$ & $\mathrm{MnO}$ & $\mathrm{Fe}_{2} \mathrm{O}_{3}$ & $\mathrm{ZnO}$ & $\mathrm{Nb}_{2} \mathrm{O}_{5}$ & $\mathrm{Ta}_{2} \mathrm{O}_{5}$ \\
\hline 1 & & 9.61 & 19.49 & 69.7 & & & & & & 1.21 & & \\
\hline 2 & & 7.60 & 19.71 & 71.41 & & & & & & 1.28 & & \\
\hline 3 & & 7.30 & 19.65 & 71.26 & & & & & & 1.8 & & \\
\hline 4 & & 11.54 & 19.3 & 69.17 & & & & & & & & \\
\hline 5 & & 9.83 & 19.31 & 68.67 & & & & & & 2.19 & & \\
\hline 6 & & 10.48 & 19.37 & 69.57 & & 0.17 & & & & 0.41 & & \\
\hline 7 & & 9.95 & 19.07 & 69.94 & 0.07 & & & & & 0.98 & & \\
\hline 8 & & 8.93 & 19.42 & 69.96 & & & & & & 1.69 & & \\
\hline 9 & & 11.45 & 19.2 & 69.2 & 0.07 & 0.08 & & & & & & \\
\hline 10 & & 11.50 & 19.14 & 69.11 & 0.15 & 0.11 & & & & & & \\
\hline 11 & & 10.07 & 21.29 & 65.28 & 0.03 & 3.34 & & & & & & \\
\hline 12 & & 10.13 & 21.01 & 66.01 & & 2.87 & & & & & & \\
\hline 13 & & 9.74 & 21.83 & 64.56 & & 3.87 & & & & & & \\
\hline 14 & & 10.17 & 21.3 & 65.63 & & 2.9 & & & & & & \\
\hline 15 & & 9.88 & 21.47 & 64.8 & & 3.85 & & & & & & \\
\hline 16 & & 10.36 & 21.05 & 65.79 & & 2.81 & & & & & & \\
\hline 17 & & 9.93 & 21.6 & 64.57 & & 3.89 & & & & & & \\
\hline 18 & & 10.75 & 20.67 & 65.88 & & 2.44 & & & 0.26 & & & \\
\hline 19 & & 9.76 & 21.83 & 64.69 & & 3.72 & & & & & & \\
\hline 20 & & 9.87 & 21.68 & 64.5 & 0.03 & 3.92 & & & & & & \\
\hline 21 & & 10.11 & 21.27 & 65.18 & & 3.44 & & & & & & \\
\hline 22 & & 10.32 & 21 & 65.54 & & 3.14 & & & & & & \\
\hline 23 & & 10.47 & 20.98 & 65.66 & & 2.89 & & & & & & \\
\hline 24 & & 10.12 & 21.3 & 65.35 & & 3.23 & & & & & & \\
\hline Minimum & & 7.30 & 19.07 & 64.50 & 0.03 & 0.08 & & & 0.26 & 0.41 & & \\
\hline maximum & & 11.54 & 21.83 & 71.41 & 0.15 & 3.92 & & & 0.26 & 2.19 & & \\
\hline Mean & & 9.99 & 20.50 & 67.14 & 0.07 & 2.75 & & & 0.26 & 1.37 & & \\
\hline
\end{tabular}

feldspars and least in tourmaline (feldspars $>$ whole rock $>$ mica $>$ tourmaline) and $\mathrm{Li}$ abundance is highest in micas and lowest in the whole rock samples (mica $>$ tourmaline $>$ feldspar $>$ whole rock).

Generally the average REE content of the pegmatites is low; $\Sigma$ REE ranges from 3 - 203 ppm, $2-26$ ppm, $4-18$ ppm and $25-33$ ppm in whole rocks, mica, feldspar and tourmaline extracts respectively with an average of $31 \mathrm{ppm}, 13$ ppm, $7 \mathrm{ppm}$ and $29 \mathrm{ppm}$ in whole rocks, mica, feldspar and tourmaline extracts. Analytical results of the major oxide, trace and rare elemental composition of pegmatites and extracts is presented in Tables 4-6. 
Table 4. Major oxide composition of pegmatites and extracts.

\begin{tabular}{ccccccc}
\hline & \multicolumn{2}{c}{$\begin{array}{c}\text { Pegmatite whole rock } \\
(\mathrm{N}=22)\end{array}$} & \multicolumn{2}{c}{ Feldspars $(\mathrm{N}=12)$} & \multicolumn{2}{c}{ Micas $(\mathrm{N}=14)$} \\
\cline { 2 - 7 } & Range (\%) & Average (\%) & Range (\%) & Average (\%) & Range (\%) & Average (\%) \\
\hline $\mathrm{SiO}_{2}$ & $69.06-81.12$ & 73.91 & $66.38-73.42$ & 70.79 & $59.7-76.79$ & 71.72 \\
$\mathrm{TiO}_{2}$ & $0-0.36$ & 0.07 & $0-0.01$ & 0.00 & $0.05-0.13$ & 0.10 \\
$\mathrm{Al}_{2} \mathrm{O}_{3}$ & $10.35-20.19$ & 13.93 & $12.71-21.27$ & 16.42 & $11.05-25.58$ & 15.33 \\
$\mathrm{Fe}_{2} \mathrm{O}_{3}$ & $0.06-3.65$ & 1.00 & $0.13-0.43$ & 0.25 & $1.7-3.58$ & 2.11 \\
$\mathrm{MnO} \mathrm{O}$ & $0-0.09$ & 0.04 & $0-0.04$ & 0.01 & $0.06-0.1$ & 0.08 \\
$\mathrm{MgO}$ & $0.02-1.87$ & 0.35 & $0.01-0.03$ & 0.02 & $0.15-0.53$ & 0.42 \\
$\mathrm{CaO}$ & $0.04-1.71$ & 0.57 & $0.04-0.91$ & 0.24 & $0.06-0.7$ & 0.53 \\
$\mathrm{Na}_{2} \mathrm{O}$ & $0.74-8.97$ & 4.3 & $2.77-10.21$ & 5.77 & $0.51-3.53$ & 2.82 \\
$\mathrm{~K}_{2} \mathrm{O}$ & $0.69-7.87$ & 4.77 & $0.66-11.33$ & 5.30 & $4.72-8.87$ & 5.66 \\
$\mathrm{P}_{2} \mathrm{O}_{5}$ & $0-0.34$ & 0.12 & $0.03-0.23$ & 0.14 & $0.07-0.21$ & 0.10 \\
\hline
\end{tabular}

\subsection{Major Element Variation}

$\mathrm{CaO}-\mathrm{Na}_{2} \mathrm{O}-\mathrm{K}_{2} \mathrm{O}$ diagram reveals a wide distribution of samples along the $\mathrm{Na}_{2} \mathrm{O}-\mathrm{K}_{2} \mathrm{O}$ sideline, coupled with the very low $\mathrm{Ca}$ contents of the pegmatites. The samples show a significant departure from the Calc-alkaline trend of [31] as well as the Trondhjemitic trend of [32]. The plot shows that the samples are mainly potassium rich with a few exceptions showing high $\mathrm{Na}_{2} \mathrm{O}$ and $\mathrm{CaO}$ composition due to the difference in feldspar type and composition (Figure 10).

\subsection{Trace Elements and Mineralization Potential}

Trace element data shows an enrichment of $\mathrm{W}, \mathrm{Li}, \mathrm{Ta}, \mathrm{Nb}$ and $\mathrm{Sn}$ in the mica with an average of $29 \mathrm{ppm}, 153 \mathrm{ppm}, 30 \mathrm{ppm}, 118 \mathrm{ppm}$ and $128 \mathrm{ppm}$ respectively which is above the average values in the whole rock, felspars and tourmaline extracts (Table 5). This prefential enrichment of some elements in the muscovite extracts can be explained by the ability of the muscovite to accommodate wide range of substitutions at various sites in its crystal structure [33] and [34].

$\mathrm{K} / \mathrm{Rb}$ vs. Cs, Ta vs. Cs, Ta vs. Ga, Ta vs. Cs, Ta vs. K/Cs and Ta vs. $\mathrm{Cs}+\mathrm{Rb}$ plots also reveals a low level of rare earth element mineralization (Figures 11(a)-(d)), based on the line of mineralization proposed by [35] and [36].

$\mathrm{Al}_{2} \mathrm{O}_{3} / \mathrm{Na}_{2} \mathrm{O}+\mathrm{K}_{2} \mathrm{O}$ vs. $\mathrm{Al}_{2} \mathrm{O}_{3} / \mathrm{CaO}+\mathrm{Na}_{2} \mathrm{O}+\mathrm{K}_{2} \mathrm{O}$ (A/NK vs. $\mathrm{A} / \mathrm{CNK}$ ) shows pegmatites are strongly peraluminous (Figure $10(\mathrm{e})$ ) and $\mathrm{K} / \mathrm{Rb}$ values range from 24 - 575 with an average of $177 \mathrm{ppm}$ (Table 7) with few samples having $\mathrm{K} / \mathrm{Rb}$ ratios less than $100 \mathrm{ppm}$ which is generally accepted as indicative of mineralization [37]. Plots of $\mathrm{Cs} v$ s. $\mathrm{K} / \mathrm{Rb}$ and $\mathrm{Ba}$ vs. $\mathrm{K} / \mathrm{Rb}$ show the pegmatites are non mineralized and belong to the muscovite class (Figure 11(f), Figure 11(g)) and they have $\mathrm{Nb} / \mathrm{Ta}$ ratios of $1-19$ (Table 7).

[38] inferred that rare metal pegmatites are typically the most distant pegmatites from their parent granites while [39] reported that classical pegmatite 
Table 5. Trace elemental concentrations of pegmatites and extracts.

\begin{tabular}{|c|c|c|c|c|c|c|c|c|}
\hline & \multicolumn{2}{|c|}{$\begin{array}{l}\text { Pegmatite whole } \\
\text { rock }(\mathrm{N}=22)\end{array}$} & \multicolumn{2}{|c|}{ Feldspars $(\mathrm{N}=12)$} & \multicolumn{2}{|c|}{ Micas $(N=14)$} & \multicolumn{2}{|c|}{ Tourmaline $(\mathrm{N}=2)$} \\
\hline & $\begin{array}{l}\text { Range } \\
\text { (ppm) }\end{array}$ & $\begin{array}{c}\text { Average } \\
(\mathrm{ppm})\end{array}$ & $\begin{array}{l}\text { Range } \\
\text { (ppm) }\end{array}$ & $\begin{array}{c}\text { Average } \\
\text { (ppm) }\end{array}$ & Range (ppm) & $\begin{array}{c}\text { Average } \\
\text { (ppm) }\end{array}$ & $\begin{array}{l}\text { Range } \\
\text { (ppm) }\end{array}$ & $\begin{array}{l}\text { Average } \\
\text { (ppm) }\end{array}$ \\
\hline Mo & Bdl-1.69 & 0.68 & Bdl-0.17 & 0.11 & $0.23-0.95$ & 0.59 & $0.26-0.3$ & 0.28 \\
\hline $\mathrm{Cu}$ & $1.6-62.1$ & 10.85 & $2-46.50$ & 10.12 & $5-14.7$ & 9.76 & $40.3-59.5$ & 49.9 \\
\hline $\mathrm{Pb}$ & $6.33-80.68$ & 37.96 & $8.88-114.93$ & 38.57 & $19.88-58.91$ & 28.89 & $4.88-5.71$ & 5.295 \\
\hline $\mathrm{Zn}$ & $1.7-65$ & 18.91 & $1.1-31$ & 10.22 & $40.2-89.5$ & 54.17 & $64.1-125$ & 94.55 \\
\hline Ag & Bdl-133 & 48.35 & Bdl-191 & 71.63 & $0.9-11.9$ & 8.24 & $20-27$ & 27 \\
\hline $\mathrm{Ni}$ & $0.4-66.5$ & 9.45 & $0.7-4.2$ & 1.79 & $0.9-3.7$ & 2.64 & $2.1-10.6$ & 6.35 \\
\hline Co & Bdl-10.3 & 3.49 & Bdl-1.1 & 0.61 & Bdl-1.7 & 1.45 & $2-3.4$ & 2.7 \\
\hline As & $0.3-3.1$ & 1.43 & Bdl-1.4 & 0.76 & Bdl-7.3 & 5.32 & $0.6-1$ & 0.8 \\
\hline $\mathrm{U}$ & $0.7-13.7$ & 4.02 & $0.2-11.2$ & 3.38 & $0.1-3.6$ & 1.51 & $6.3-6.8$ & 6.55 \\
\hline Th & $0.1-23.7$ & 4.1 & Bdl-2.7 & 0.83 & $3-46$ & 35.57 & $1.0-1.2$ & 1.2 \\
\hline $\mathrm{Sr}$ & $3-139$ & 49.77 & $3-72$ & 18.58 & $0.05-0.14$ & 0.09 & $3-27$ & 15 \\
\hline $\mathrm{Cd}$ & Bdl- 0.18 & 0.08 & Bdl-0.21 & 0.08 & $0.2-1.73$ & 1.30 & $0.14-0.19$ & 0.165 \\
\hline $\mathrm{Sb}$ & $0.03-2.95$ & 0.54 & Bdl-1.64 & 0.40 & $0.06-0.55$ & 0.41 & $6.59-20.28$ & 13.435 \\
\hline $\mathrm{Bi}$ & $0.04-36.28$ & 2.05 & $0.09-26.46$ & 2.75 & $2-20$ & 15.21 & $2-13$ & 7.5 \\
\hline $\mathrm{Cr}$ & Bdl-100 & 14.86 & $1-4$ & 2.50 & $4-16$ & 12.71 & $4-7$ & 5.5 \\
\hline $\mathrm{Ba}$ & $11-549$ & 217.27 & $12-671$ & 119.92 & $7-133$ & 98.79 & $6-32$ & 19 \\
\hline $\mathrm{W}$ & $0.1-5.3$ & 1.42 & Bdl-1.3 & 0.54 & $16.3-55.6$ & 28.61 & $0.2-0.3$ & 0.25 \\
\hline $\mathrm{Zr}$ & $0.6-132.2$ & 30.85 & Bdl-131 & 27.80 & $2-11.4$ & 6.69 & $7.6-27.9$ & 17.75 \\
\hline Sn & $0.3-6.6$ & 2.88 & $0.2-5.1$ & 2.18 & $8.4-573.9$ & 128.64 & $0.5-0.5$ & 0.6 \\
\hline $\mathrm{Be}$ & $1-18$ & 5.36 & Bdl-16 & 7.36 & $5-19$ & 8.57 & $1-2$ & 2 \\
\hline Sc & $0.3-6.4$ & 2.0 & $0.3-0.6$ & 0.42 & $2.1-5.8$ & 4.39 & $1-3.6$ & 2.3 \\
\hline $\mathrm{Y}$ & $0.7-15.2$ & 4.64 & Bdl-7 & 2.1 & $0.1-6.3$ & 4.07 & $11.6-30.1$ & 20.85 \\
\hline $\mathrm{Hf}$ & $0.03-9.55$ & 1.96 & Bdl9.51 & 2.63 & $0.5-1.02$ & 0.70 & $0.3-0.79$ & 0.545 \\
\hline $\mathrm{Li}$ & $2.3-216.3$ & 42.22 & $7-295.9$ & 57.53 & $69.6-437.1$ & 152.76 & $15.6-374.1$ & 194.85 \\
\hline $\mathrm{Rb}$ & $12-1130$ & 247.42 & $8->2000$ & 716.67 & $304->2000$ & 696.03 & $0.8-7.7$ & 4.25 \\
\hline $\mathrm{Ta}$ & $0.4-52.8$ & 9.48 & Bdl-44.1 & 14.93 & $21.8-45.70$ & 30.61 & $0.2-12$ & 6.1 \\
\hline $\mathrm{Nb}$ & $1.2-170.01$ & 32.24 & $0.31-106.63$ & 28.91 & $59.17-314.85$ & 118.61 & $1.85-7.91$ & 4.88 \\
\hline Cs & $0.7-127.1$ & 32.81 & $2-113.30$ & 44.68 & $14-53.70$ & 23.71 & $1.4-1.9$ & 1.65 \\
\hline $\mathrm{Ga}$ & $9.41-35.53$ & 20.03 & $11.95-37.72$ & 22.65 & $27.68->100$ & 45.67 & $10.22-10.45$ & 10.335 \\
\hline $\mathrm{Tl}$ & Bdl-30 & 5.47 & Bdl-4.15 & 1.24 & $1.51-12.65$ & 3.94 & - & - \\
\hline
\end{tabular}

zonation is typical of highly fractionated and mineralized pegmatites. The low level of rare earth mineralisation in this area is supported by lack of definate zonation patterns in the pegmatites and proximity to parent granitic bodies. 
Table 6. Rare earth element composition of pegmatites and extracts.

\begin{tabular}{ccccccccc}
\hline & $\begin{array}{c}\text { Pegmatite whole rock } \\
(\mathrm{N}=22)\end{array}$ & \multicolumn{2}{c}{ Feldspars $(\mathrm{N}=12)$} & \multicolumn{2}{c}{ Micas $(\mathrm{N}=14)$} & \multicolumn{2}{c}{ Tourmaline (N = 2) } \\
\cline { 2 - 9 } & $\begin{array}{c}\text { Range } \\
(\mathrm{ppm})\end{array}$ & $\begin{array}{c}\text { Average } \\
(\mathrm{ppm})\end{array}$ & $\begin{array}{c}\text { Range } \\
(\mathrm{ppm})\end{array}$ & $\begin{array}{c}\text { Average } \\
(\mathrm{ppm})\end{array}$ & Range & $\begin{array}{c}\text { Average } \\
(\mathrm{ppm})\end{array}$ & $\begin{array}{c}\text { Range } \\
(\mathrm{ppm})\end{array}$ & $\begin{array}{c}\text { Average } \\
(\mathrm{ppm})\end{array}$ \\
\hline $\mathrm{La}$ & $0.4-46.6$ & 6.04 & $0.20-4.90$ & 2.19 & $2.5-4.1$ & 3.3 & $0.20-4.6$ & 1.12 \\
$\mathrm{Ce}$ & $0.68-90.99$ & 12.28 & $0.90-10.50$ & 4.85 & $6.31-6.56$ & 6.4 & $0.19-4.14$ & 1.76 \\
$\mathrm{Pr}$ & $0.2-9.8$ & 1.67 & Bdl-1.20 & 0.75 & $0.9-1$ & 0.95 & $0.1-0.9$ & 0.37 \\
$\mathrm{Nd}$ & $0.4-35.7$ & 5.6 & $0.20-4.80$ & 2.32 & $4.1-5$ & 4.55 & $0.20-3.4$ & 1.38 \\
$\mathrm{Sm}$ & $0.2-6.2$ & 1.45 & Bdl-1.20 & 0.81 & $1.4-2.7$ & 2.05 & $0.10-1.2$ & 0.49 \\
$\mathrm{Eu}$ & $0.1-0.9$ & 0.14 & Bdl-0.20 & 0.16 & $0.2-0.3$ & 0.25 & $0.10-0.3$ & 0.17 \\
$\mathrm{Gd}$ & $0.2-4.8$ & 1.13 & Bdl-1.10 & 0.63 & $1.4-3.8$ & 2.6 & $0.10-1.1$ & 0.49 \\
$\mathrm{~Tb}$ & - & - & - & - & $0.2-0.8$ & 0.5 & - & - \\
$\mathrm{Dy}$ & $0.2-3.1$ & 0.92 & Bdl-0.80 & 0.67 & $1.8-5.2$ & 3.5 & $0.10-1.2$ & 0.46 \\
$\mathrm{Ho}$ & $0.1-0.7$ & 0.25 & Bdl-0.20 & 0.12 & $0.3-0.9$ & 0.6 & - & - \\
$\mathrm{Er}$ & $0.1-1.5$ & 0.5 & Bdl-0.40 & 0.33 & $1.1-2.2$ & 1.65 & - & - \\
$\mathrm{Tm}$ & - & - & - & - & $0.2-0.4$ & 0.3 & - & - \\
$\mathrm{Yb}$ & $0.1-3$ & 0.74 & Bdl-0.70 & 0.57 & $1.5-2.4$ & 1.95 & $0.10-1.1$ & 0.37 \\
$\mathrm{Lu}$ & - & - & - & - & $0.2-0.3$ & 0.25 & - & - \\
\hline
\end{tabular}

Bdl-below detection limit. -No data

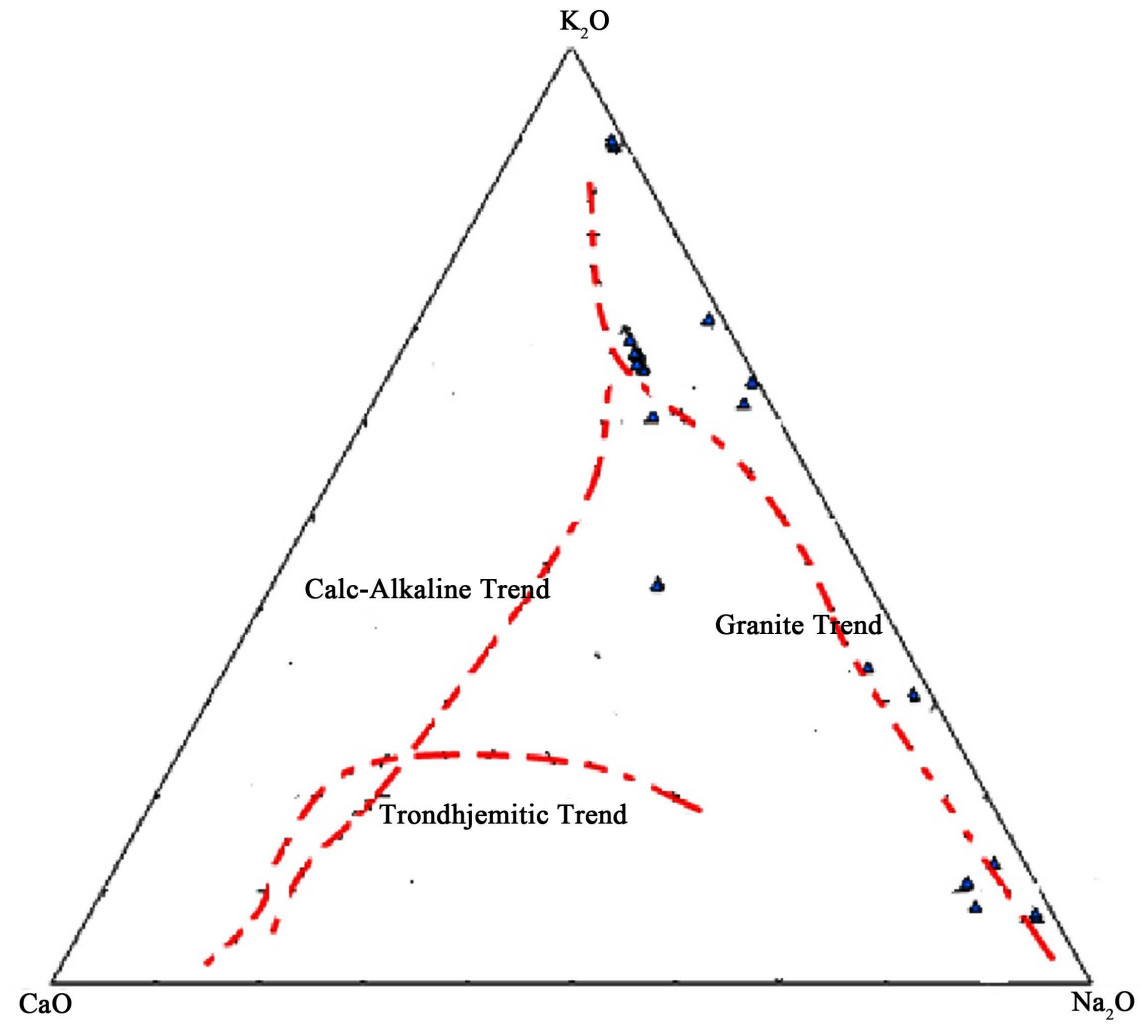

Figure 10. $\mathrm{CaO}-\mathrm{Na}_{2} \mathrm{O}-\mathrm{K}_{2} \mathrm{O}$ ternary variation diagram for whole rock pegmatites. 
Table 7. Selected elemental ratios of whole rock pegmatites.

\begin{tabular}{|c|c|c|c|c|c|c|c|c|}
\hline S/NO & A/CNK & A/NK & $\mathrm{K}_{2} \mathrm{O} / \mathrm{Na}_{2} \mathrm{O}$ & $\mathrm{Ba} / \mathrm{Rb}$ & $\mathrm{Rb} / \mathrm{Sr}$ & $\mathrm{Rb} / \mathrm{Cs}$ & $\mathrm{K} / \mathrm{Rb}$ & $\mathrm{Nb} / \mathrm{Ta}$ \\
\hline 1 & 1.22 & 1.23 & 1.8 & 1.5 & 12.0 & 58.5 & 233.0 & 19.4 \\
\hline 2 & 1.42 & 1.46 & 0.2 & 0.7 & 0.6 & 43.9 & 327.1 & 8.0 \\
\hline 3 & 1.20 & 1.22 & 2.6 & 0.2 & 20.2 & 33.1 & 179.7 & 6.4 \\
\hline 4 & 1.24 & 1.34 & 0.1 & 0.9 & 0.6 & 0.5 & 574.5 & 3.1 \\
\hline 5 & 1.15 & 1.18 & 1.7 & 0.7 & 7.7 & 25.5 & 211.3 & 12.5 \\
\hline 6 & 1.36 & 1.45 & 0.1 & 0.4 & 3.2 & 0.6 & 161.3 & 1.3 \\
\hline 7 & 1.18 & 1.24 & 0.6 & 5.9 & 1.3 & 21.6 & 362.4 & 10.4 \\
\hline 8 & 1.56 & 1.59 & 0.1 & 0.2 & 26.3 & 35.8 & 72.7 & 3.2 \\
\hline 9 & 1.24 & 1.38 & 2.7 & 1.4 & 3.2 & 12.8 & 173.5 & 3.9 \\
\hline 10 & 1.61 & 1.64 & 0.1 & 0.3 & 25.8 & 35.1 & 74.1 & 2.4 \\
\hline 11 & 1.13 & 1.26 & 3.2 & 1.2 & 3.5 & 14.1 & 176.8 & 4.8 \\
\hline 12 & 1.17 & 1.30 & 3.0 & 1.3 & 3.5 & 13.7 & 177.2 & 4.5 \\
\hline 13 & 1.67 & 1.70 & 0.5 & 0.0 & 141.2 & 29.5 & 23.8 & 2.5 \\
\hline 14 & 2.31 & 2.33 & 10.1 & 0.0 & 117.6 & 15.7 & 32.7 & 0.9 \\
\hline 15 & 1.20 & 1.33 & 2.9 & 1.3 & 3.5 & 13.2 & 174.2 & 5.0 \\
\hline 16 & 2.46 & 2.50 & 9.7 & 0.0 & 125.0 & 16.1 & 30.2 & 0.7 \\
\hline 17 & 1.41 & 1.60 & 2.2 & 1.6 & 2.8 & 10.9 & 160.6 & 3.9 \\
\hline 18 & 2.18 & 2.21 & 10.3 & 0.0 & 133.3 & 15.8 & 31.5 & 0.5 \\
\hline 19 & 1.43 & 1.79 & 1.2 & 5.5 & 0.7 & 45.2 & 296.1 & 11.5 \\
\hline 20 & 1.64 & 1.67 & 0.1 & 0.2 & 26.6 & 34.7 & 77.0 & 2.8 \\
\hline 21 & 1.21 & 1.34 & 3.0 & 1.3 & 3.4 & 13.4 & 180.1 & 3.9 \\
\hline 22 & 1.27 & 1.43 & 2.9 & 1.2 & 3.5 & 13.8 & 162.4 & 2.6 \\
\hline mean & 1.47 & 1.55 & 2.68 & 1.18 & 30.26 & 22.89 & 176.92 & 5.19 \\
\hline
\end{tabular}

The rare-earth elements abundance of bulk rock and mineral extracts (muscovite and feldspar) of pegmatites from the study area are presented in Table 5.

Generally, the REE pattern of the bulk pegmatite samples and the mineral extracts display different REE patterns (Figure 12), REE abundance in whole rock pegmatites is low to moderately high with $\Sigma$ REE varying between $7.67-220.37$ ppm, a weak negative $\mathrm{Eu}$ anomy $\left(\mathrm{Eu} / \mathrm{Eu}^{*}=0.15-1.53\right)$, a slightly discernable negative Ce anomaly and relative enrichment of $\operatorname{HREE}\left(\mathrm{La}_{\mathrm{N}} / \mathrm{Yb}_{\mathrm{N}}=0.96-25.82\right)$.

Based on the normalization plots; the pegmatites did not undergo considerable fractionation and metasomatism as well as the study of [42] that advanced the views that weak negative Ce signature and a strong negative Eu signature denotes considerable fractionation and metasomatism.

\section{Conclusion}

The study area which is majorly underlain by schist and potassic porphyritic 


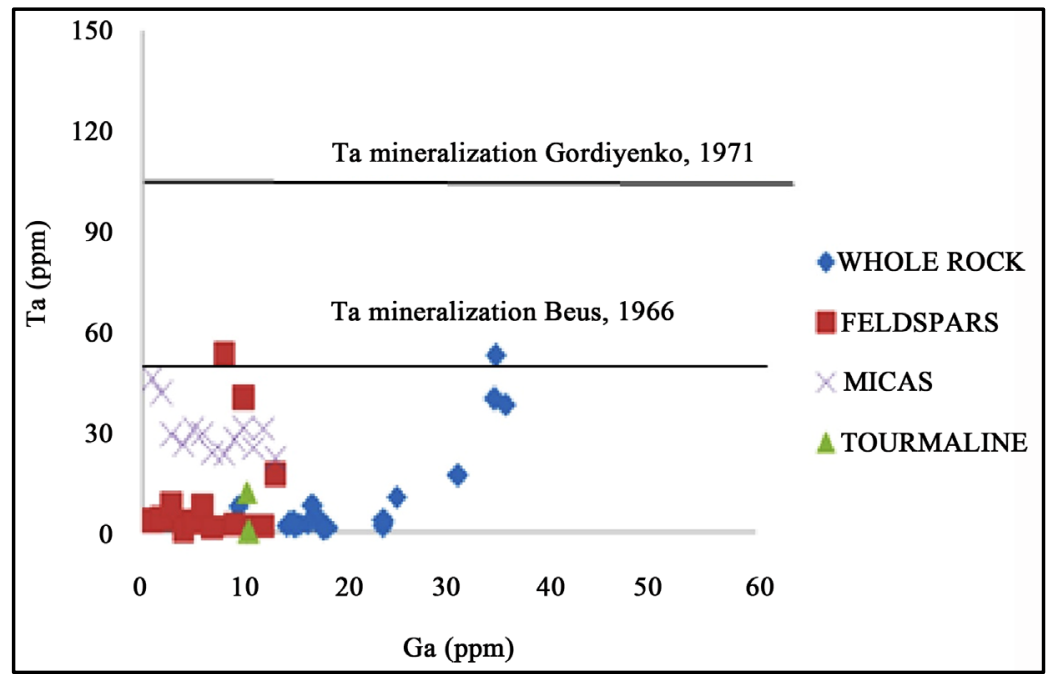

(a)

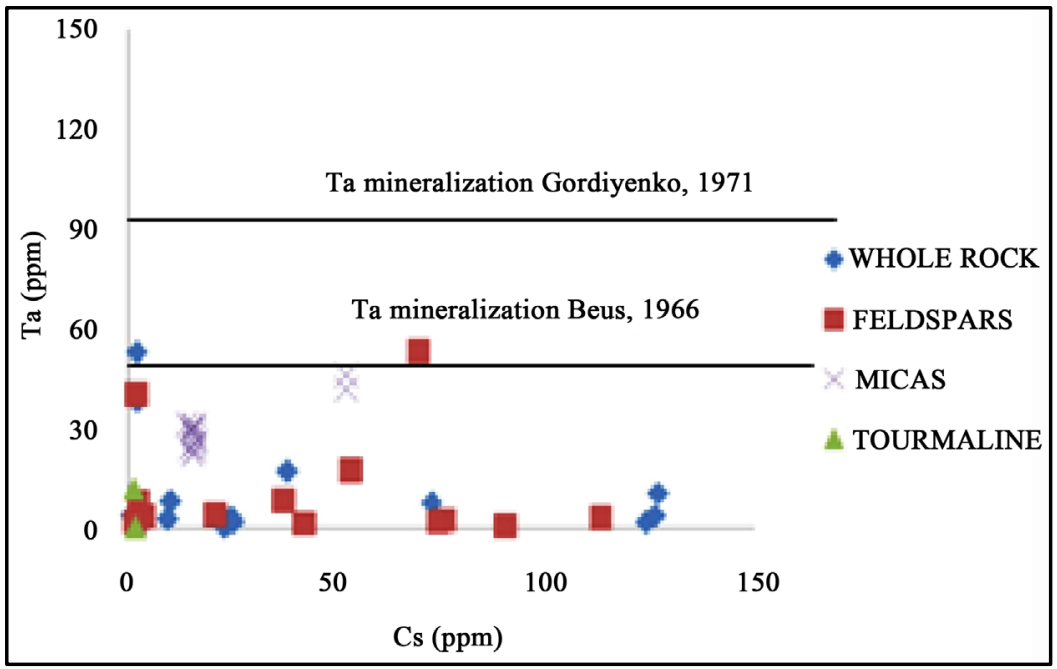

(b)

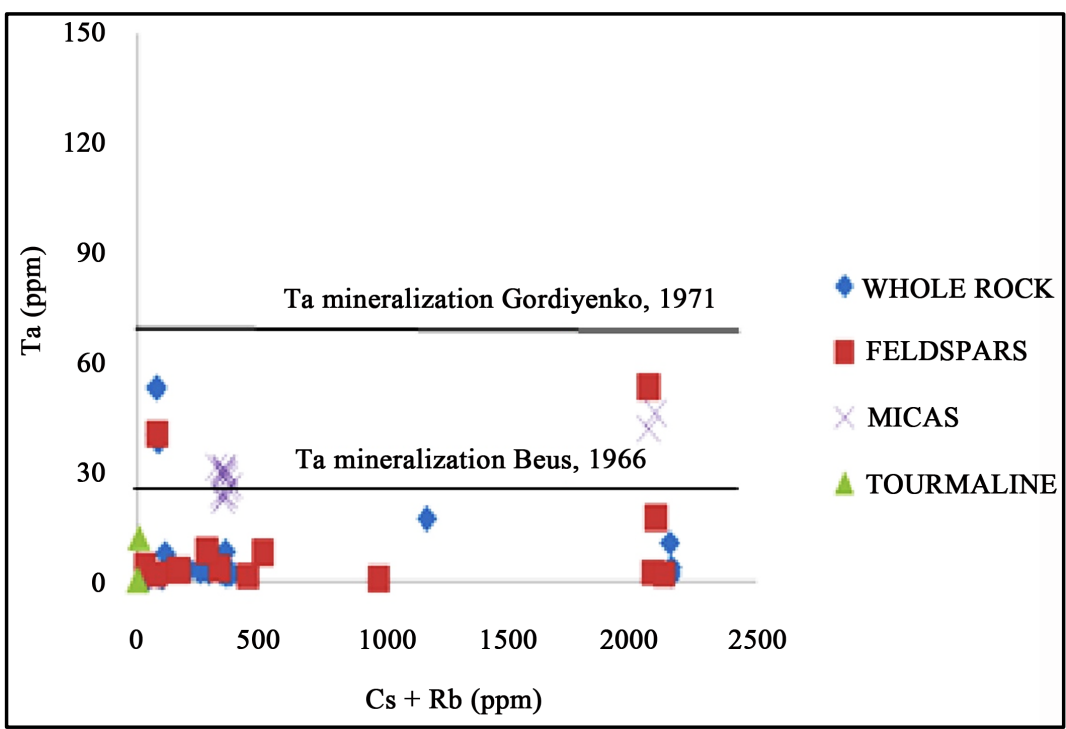

(c) 


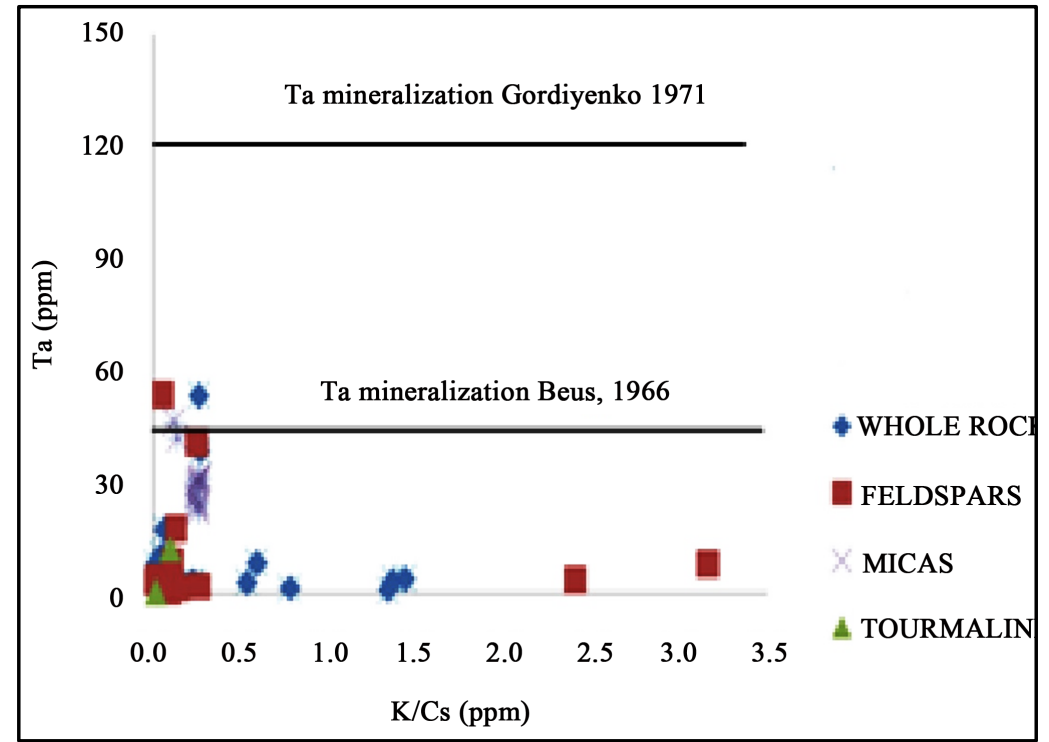

(d)

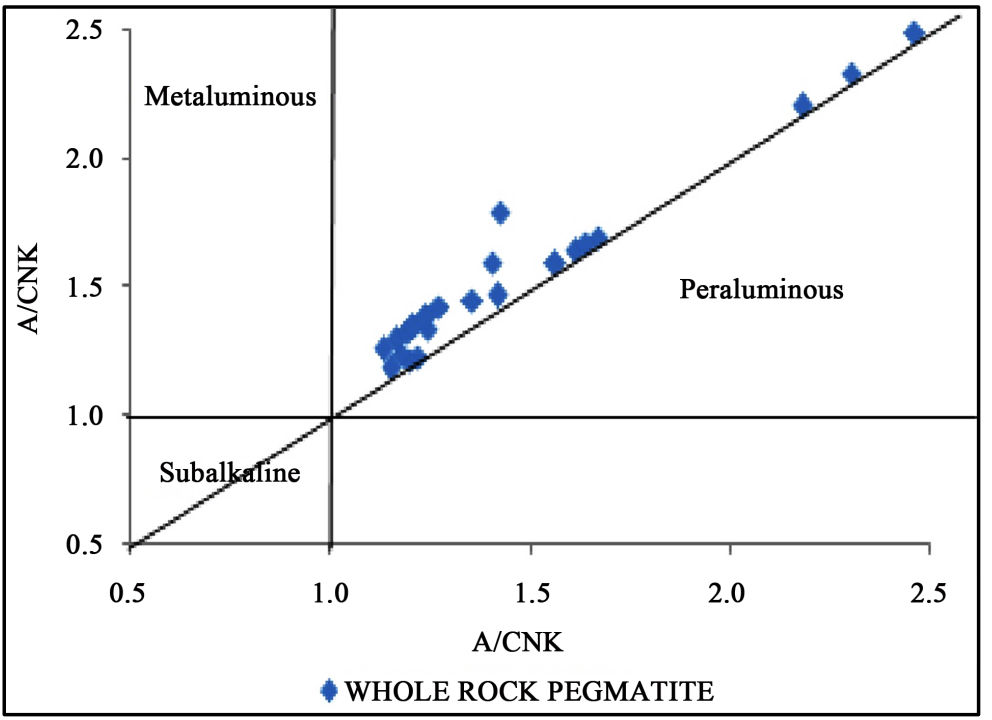

(e)

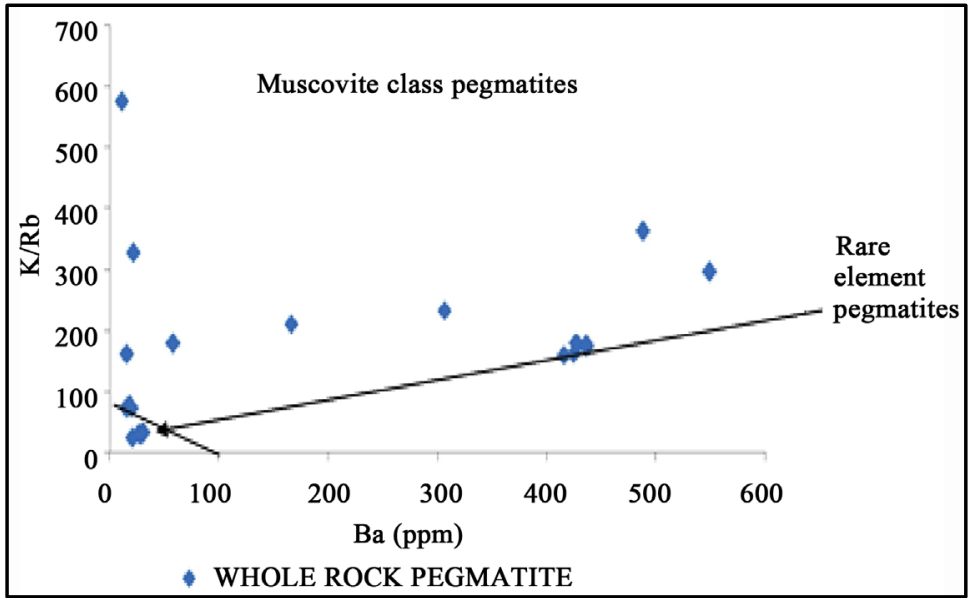

(f) 


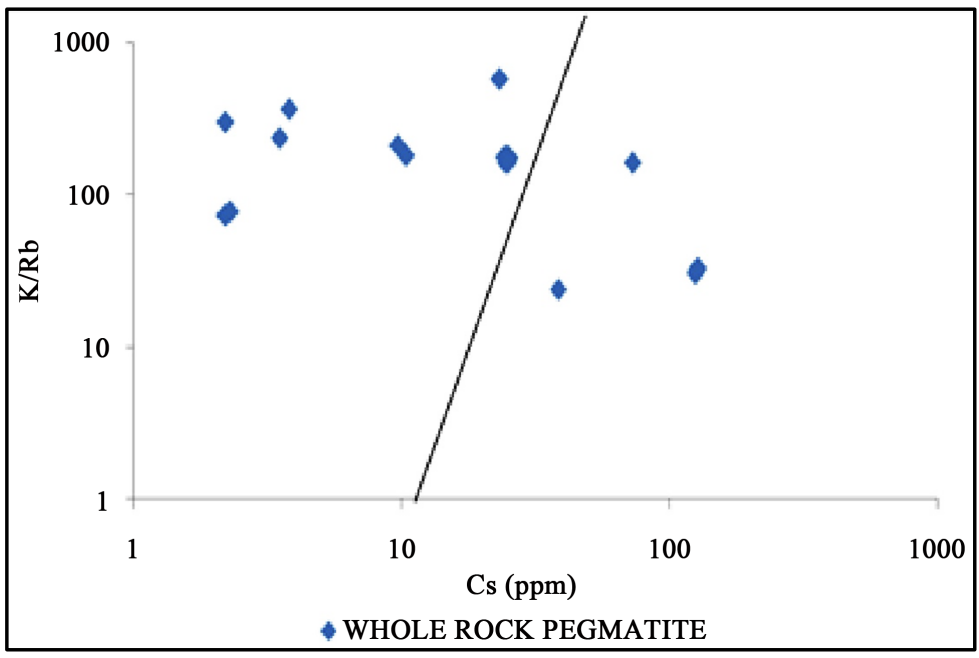

(g)

Figure 11. (a)-(g). (a) Ta vs Ga plot for pegmatitess and extracts from the study area; (b) Ta vs Cs plot; (c) Ta vs Cs + Rb; (d) Ta vs K/Cs; (e) molar A/NK vs. A/CNK (after [40]); (f) and (g) mineralization potentials and characterization of the pegmatites (discrimination lines after [41]).

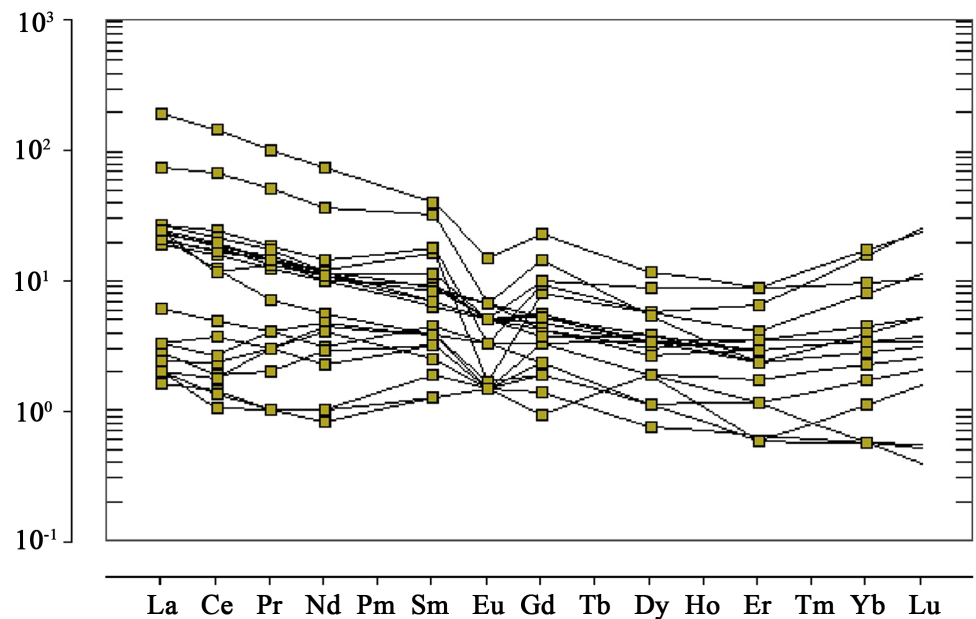

Figure 12. Condrite normalization plot for pegmatites and extracts. (condrite values after[43])

granites has been intruded by low lying NW-SE trending pegmatites. Results of geochemical analysis as well as trace elemental plots revealed low to medium enrichment in rare metals and REEs though there is potential for gem winning based on previous winnings of gems from the study area, unfortunately, there is no clear cut geochemical method to ascertain the presence or absence of gemstones in pegmatites from surface samples.

\section{Further Studies}

Understanding the genesis of pegmatites still remains a controversial topic. Further studies can be carried out using oxygen and hydrogen isotopes in conjunc- 
tion with fluid inclusion studies (in progress) to obtain more information on the petrogenesis of these pegmatites and the mineralogy can further be studied to understand further the mineral species and delineate minerals which might be used to understand the genesis of the pegmatite and delineate the gem bearing zones.

\section{Acknowledgements}

This study is part of the $\mathrm{PhD}$ thesis of OOG. OOG acknowledges the research grant and PhD scholarship received from the African University Commission to pursue his studies. Olajide-Kayode, J. O., Popoola, O. and Sobhy, M. and others who assisted during the field work are appreciated. Two anonymous reviewers whose comments improved this manuscript are appreciated.

\section{References}

[1] London, D. (2005) Geochemistry of Alkalis and Alkali Earths in Ore-Forming Granites, Pegmatites, and Rhyolites. In: Linnen, R. and Samson, I., Eds., Rare Element Geochemistry of Ore Deposits, Geological Association of Canada, Short Course Handbook 17, 17-43.

[2] London, D. (2008) Pegmatites. Special Publications of the Canadian Mineralogist, Volume 10, Mineralogical Association of Canada.

[3] Hulsbosch, N., Hertogen, J., Dewaele, S., André, L. and Muchez, P. (2014) Alkali Metal and Rare Earth Element Evolution of Rock-Forming Minerals from the Gatumba Area Pegmatites (Rwanda): Quantitative Assessment of Crystal-Melt Fractionation in the Regional Zonation of Pegmatite Groups. Geochimica et Cosmochimica Acta, 132, 349-374. https://doi.org/10.1016/j.gca.2014.02.006

[4] Okunlola, O.A. and Akintola, A.I. (2007) Geochemical Features and Rare Metal $\mathrm{Ta}-\mathrm{Nb}$ Potentials of Precambrian Pegmatites of Sepeteri Area, Southwestern Nigeria. Ife Journal of Science, 9, 203-214.

[5] Okunlola, O.A. and Jimba, S. (2006) Compositional Trends in Relation to Ta-Nb Mineralization in Precambrian Pegmatites of Aramoko-Ara-Ijero Area, Southwestern Nigeria. Journal of Mining and Geology, 42, 113-126.

[6] Adedoyin, A.D., Adekeye, J.I.D. and Alao, D.A. (2006) Trace Element Geochemistry of Selected Pegmatites from Southwestern Nigeria. Nigerian Journal of Pure and Applied Science, 21, 2023-2035.

[7] Okunlola, O.A. and Ocan, O.O. (2009) Rare Metal (Ta-Sn-Li-Be) Distribution in Precambrian Pegmatites of Keffi Area, Central Nigeria. Nature and Science, 7, 90-99.

[8] Okunlola, O.A. and Akinola, O.O. (2010) Petrochemical Characteristics of the Precambrian Rare Metal Pegmatite of Oke-Asa Area, Southwestern Nigeria: Implication for Ta-Nb Mineralization. RMZ-Materials and Geoenvironment, 57, 525-538.

[9] Okunlola, O.A. and Somorin, E.B. (2005) Compositional Features of Precambrian Pegmatites of Itakpe Area, Central Nigeria. Global Journal of Geological Sciences, 4, 221-230.

[10] Akintola, A.I., Ikhane, P.R., Okunlola, O.A., Akintola, G.O. and Oyebolu, O.O. (2012) Compositional Features of Precambrian Pegmatites of Ago-Iwoye Area South Western, Nigeria. Journal of Ecology and the Natural Environment, 4, 71-87. 
[11] Garba, I. (2002) Late Pan African Tectonics and Origin of Gold Mineralization and Rare Metal Pegmatites in the Kushaka Schist Belt, North Western Nigeria. Journal of Mining and Geology, 38, 1-12. https://doi.org/10.4314/jmg.v38i1.18768

[12] Okunlola, O.A. (2005) Metallogeny of Tantalum-Niobium Mineralization of Precambrian Pegmatites of Nigeria. Mineral Wealth, 137, 38-50.

[13] Jacobson, R. and Webb, J.S. (1946) The Pegmatites of Central Nigeria. Geological Survey of Nigeria, 17, 1-61.

[14] Kinnard, J.A. (1984) Contrasting Styles of Sn-Nb-Ta-Zn Mineralization in Nigeria. Journal of African and Earth Sciences, 2, 81-90. https://doi.org/10.1016/S0731-7247(84)80001-4

[15] Garba, I. (2003) Geochemical Discrimination of Newly Discovered Rare Metal Bearing and Barren Pegmatites in the Pan-African $(600+150 \mathrm{Ma})$ Basement of Northern Nigeria. Applied Earth Science Transaction Institute of Mining and Mettallurgy, 112, B287-B291. https://doi.org/10.1179/037174503225011270

[16] Adetunji, A., Olarewaju, V.O, Ocan, O.O., Ganev, V.Y. and Macheva, L. (2016) Geochemistry and U-Pb Zircon Geochronology of the Pegmatites in Ede Area, Southwestern Nigeria: A Newly Discovered Oldest Pan African Rock in Southwestern Nigeria. Journal of African Earth Sciences, 115, 177-190. https://doi.org/10.1016/j.jafrearsci.2015.12.006

[17] Burke, K.C. and Dewey, J.F. (1972) Orogeny in Africa. In: Dessavagie, T.F.J. and Whiteman, A.J., Eds., African Geology, Ibadan University Press, Ibadan, 583-608.

[18] Leblanc, M. (1981) The Late Proterozoic Ophiolites of Bou Azzer (Morocco): Evidence for Pan-African Plate Tectonics. In: Kroner, A., Ed., Precambrian Plate Tectonics, Elsevier, Amsterdam, 435-451.

[19] Black, R., Caby, R., Moussine-Pouchkine, A., Bayer, R., Betrand, J.M., Boullier, M.M., Fabre, J. and Resquer, A. (1979) Evidence for Late Precambrian Plate Tectonics in West Africa. Nature, 278, 223-227.

https://doi.org/10.1038/278223a0

[20] Caby, R., Betrand, J.M.L. and Black, R. (1981) Pan-African Ocean Closure and Continental Collision in the Hogger-Iforas Segment, Central Sahara. In: Kroner, A., Ed., Precambrian Plate Tectonics, Elsevier, Amsterdam, 407-437.

[21] Turner, D.C. (1983) Upper Proterozoic Schist Belts in the Nigerian Sector of the Pan African Province of West Africa. Precambrian Research, 21, 55-79. https://doi.org/10.1016/0301-9268(83)90005-0

[22] Oversby, V.M. (1975) Lead Isotopic Study of Aplites from the Precambrian Basement Rocks near Ibadan, Southwestern Nigeria. Earth and Planetary Science Letters, 27, 177-180. https://doi.org/10.1016/0012-821X(75)90027-8

[23] McCurry, P. and Wright, J.B. (1977) Geochemistry of Clc-Alkaline Volcanics in Northwestern Nigeria, and a Possible Pan African Suture Zone. Earth Planetary science Letters, 37, 90-96. https://doi.org/10.1016/0012-821X(77)90149-2

[24] Annor, A.E. and Freeth, S.J. (1985) Thermometric Evolution of the Basement Complex around Okene, Nigeria, with Special Reference to Deformation Mechanisms. Precambrian Research, 28, 269-281. https://doi.org/10.1016/0301-9268(85)90034-8

[25] Rahaman, M.A. (1988) Recent Advances in the Study of the Basement Complex of Nigeria. In: Oluyide, P.O., Mbonu, W.C. and Ogezi, A.E., Eds., Precambrian Geology of Nigeria, Geological Survey of Nigeria Publication, Kaduna, 11-41.

[26] Grant, N.K., Hickman, M., Burkholder, F.R. and Powell, J.I. (1972) Kibaran Metamorphic Belt in the Pan African Domain of North Western Nigeria. Geological So- 
ciety of America Bulletin, 89, 50-58.

https://doi.org/10.1130/0016-7606(1978)89<50:SDBAMC >2.0.CO;2

[27] Toteu, S.F., Penaye, J. and Djomani, Y.P. (2004) Geodynamic Evolution of the Pan-African Belt in Central Africa with Special Reference to Cameroon. Canadian Journal of Earth Science, 41, 73-85. https://doi.org/10.1139/e03-079

[28] Obaje, N.G. (2009) Geology and Mineral Resources of Nigeria. Lecture Notes in Earth Sciences, Vol. 120, Springer-Verlag, Berlin/Heidelberg. https://doi.org/10.1007/978-3-540-92685-6

[29] Miller, C.F. and Stoddard, E.F. (1981) The Role of Manganese in the Paragenesis of Magmatic Garnet: An Example from the Old Woman Piute Range, California. Journal of Geology, 89, 233-246. https://doi.org/10.1086/628582

[30] Henry, D.J. and Guidotti, C.V. (1985) Tourmaline as a Petrogenetic Indicator Mineral: An Example from the Staurolite-Grade Metapelites of NW Maine. American Mineralogist, 70, 1-15.

[31] Nocklods, S.R. and Allen, R. (1953) The Geochemistry of Some Igneous Rock Series. Geochemica et Cosmochimica Acta, 4, 105-142. https://doi.org/10.1016/0016-7037(53)90055-6

[32] Barker, F. and Arth, J.G. (1976) Generation of Trondhjemitic-Tonalitic Liquids and Archean Bimodal Trondhjemite-Basalt Suites. Geology, 4, 596-600. https://doi.org/10.1130/0091-7613(1976)4<596:GOTLAA>2.0.CO;2

[33] Belyankina, Y.D. and Petrov, V.P. (1983) Geochemical Role of Micas in Mineral Associations: Classification Chemistry, and Genesis of Micas. International Geology Review, 25, 993-1003. https://doi.org/10.1080/00206818309466794

[34] Bailey, S.W. (1984) Structures, Classification, and Crystal Chemistry of Micas. In: Bailey, S.W., Ed., The Micas, Reviews in Mineralogy, Vol. 13, Mineralogical Society of America, 1-57.

[35] Gordiyenko, V.V. (1970) Concentration of Li, Rb, Cs in Potash Feldspar and Muscovite as Criteria for Assessing Rare Metal Mineralization in Granite Pegmatites. International Geology Review, 13, 134-142. https://doi.org/10.1080/00206817109475411

[36] Beus, A.A. (1996) Distribution of Tantalum and Niobium in Muscovites from Granitic Pegmatites. Geokhima, 10, 1216-1220.

[37] Tischendorf, G. (1977) Geochemical and Petrographic Characteristics of Silicic Magmatic Rocks Associated with Rare-Element Mineralization. In: Stemprok, M., Burnol, L. and Tischendorf, G, Eds., IGCP Mineralization Associated with Acid Magmatism, Vol. 2, Geological Survey, Prague, 41-98.

[38] Trueman, D.L. and Cerny, P. (1982) Exploration for Rare-Element Granitic Pegmatites. In: Cerny, P., Ed., Granitic Pegmatites in Science and Industry. Mineralogical Association of Canada Short Course Handbook, Vol. 8, 463-494.

[39] Sweetapple, M.T. (2000) Characteristics of Sn-Ta-Be-Li-Industrial Mineral Deposits of the Archaean Pilbara Craton, Western Australia. Australian Geological Survey Organisation Record 2000/44, 54 p.

[40] Maniar, P.D. and Piccoli, P.M. (1989) Tectonic Discrimination of Granitoids. Geological Society of America Bulletin, 101, 635-643. https://doi.org/10.1130/0016-7606(1989)101<0635:TDOG>2.3.CO;2

[41] Cerny, P. and Burt, M. (1984) Paragenesis, Crystallochemical Characteristics and Geochemical Evolution of Micas in Granitic Pegmatites. In: Bailly, S.W., Ed., Micas, Reviews in Mineralogy, Vol. 13, Mineralogical Society of America, 257-297. 
[42] Taylor, S.R., Rudnick, R.L., Mc Lennen, S.C. and Eriksson, K.A. (1986) Rare Earth Element Patterns in Archaen High Grade Metasediments and Their Tectonic Significance. Geochimica et Cosmochimica Acta, 50, 2267-2279.

https://doi.org/10.1016/0016-7037(86)90081-5

[43] Sun, S.S. and McDonough, W.F. (1989) Chemical and Isotopic Systematics of Oceanic Basalts: Implications for Mantle Composition and Processes. In: Saunders, A.D. and Norry, M.J., Eds., Magmatism in the Ocean Basins, Geological Society, London, Special Publications, Vol. 42, 313-345.

https://doi.org/10.1144/GSL.SP.1989.042.01.19 